\title{
Cathode Design for Proton Exchange Membrane Fuel Cells in Automotive Applications
}

\author{
Haojie Wang ${ }^{1} \cdot$ Ruiqing Wang ${ }^{2} \cdot$ Sheng $\mathrm{Sui}^{2} \cdot$ Tai Sun $^{3} \cdot$ Yichang Yan $^{4} \cdot$ Shangfeng $\mathrm{Du}^{4} \mathbb{( 1 )}$
}

Received: 21 November 2020 / Accepted: 22 March 2021 / Published online: 21 April 2021

(c) The Author(s) 2021

\begin{abstract}
An advanced cathode design can improve the power performance and durability of proton exchange membrane fuel cells (PEMFCs), thus reducing the stack cost of fuel cell vehicles (FCVs). Recent studies on highly active Pt alloy catalysts, shortside-chain polyfluorinated sulfonic acid (PFSA) ionomer and 3D-ordered electrodes have imparted PEMFCs with boosted power density. To achieve the compacted stack target of $6 \mathrm{~kW} / \mathrm{L}$ or above for the wide commercialization of FCVs, developing available cathodes for high-power-density operation is critical for the PEMFC. However, current developments still remain extremely challenging with respect to highly active and stable catalysts in practical operation, controlled distribution of ionomer on the catalyst surface for reducing catalyst poisoning and oxygen penetration losses and 3D (three-dimensional)ordered catalyst layers with low Knudsen diffusion losses of oxygen molecular. This review paper focuses on impacts of the cathode development on automotive fuel cell systems and concludes design directions to provide the greatest benefit.
\end{abstract}

Keywords Fuel cell vehicle (FCV) · Proton exchange membrane fuel cell (PEMFC) · Cathode $\cdot$ Mass transport · Ionomer

$\begin{array}{ll}\text { Abbreviations } \\ \text { CCL } & \text { Cathode catalyst layer } \\ \text { CL } & \text { Catalyst layer } \\ \text { CNT } & \text { Carbon nanotube } \\ \text { ECSA } & \text { Electrochemical surface area } \\ \text { EW } & \text { Equivalent weight } \\ \text { FCV } & \text { Fuel cell vehicle } \\ \text { GDE } & \text { Gas diffusion electrode } \\ \text { GDL } & \text { Gas diffusion layer } \\ \text { LSC } & \text { Long-side chain } \\ \text { MEA } & \text { Membrane electrode assembly } \\ \text { MPL } & \text { Microporous layer }\end{array}$

Sheng Sui

ssui@sjtu.edu.cn

Shangfeng Du

s.du@bham.ac.uk

1 School of Mechanical and Power Engineering, East China University of Science and Technology, Shanghai 200237, China

2 Institute of Fuel Cells, Shanghai Jiao Tong University, Shanghai 200240, China

3 Research Institute of Rare Metals, Guangdong Academy of Sciences, Guangzhou 510650, Guangdong, China

4 School of Chemical Engineering, University of Birmingham, Birmingham B15 2TT, UK

\author{
ORR Oxygen reduction reaction \\ PBI Polybenzimidazole \\ PEG Polyethylene glycol \\ PEM Proton exchange membrane \\ PEMFC Proton exchange membrane fuel cell \\ PFSA Polyfluorinated sulfonic acid \\ PGM Platinum group metal \\ PTFE Polytetrafluoroethylene \\ RDE Rotating disk electrode \\ TPB Triple-phase boundary
}

\section{Introduction}

Fuel cells convert chemical energy from the reaction of a fuel (hydrogen or hydrocarbons) and an oxidant (i.e., oxygen) directly into electricity with high efficiency and environmental benefits (zero or low emission). The fuel cell technology has been successfully used in many applications, such as stationary power generation for electricity grid, automobile vehicles and portable power devices [1]. Among all types of fuel cells, PEMFC is one of the most promising alternatives to internal combustion engines (ICEs) as power sources for transportation because PEMFCs operate at close to ambient conditions, enabling fast start-up and shut-down [2]. Since the first use for the Gemini spacecraft 
by General Electric (GE) in the 1960s, the PEMFC technology goes through a long way to access commercialization [3]. Japan, South Korea, the US, European nations and China have successively formulated visions and roadmaps of hydrogen and fuel cells, and lead commercialization of fuel cell electric vehicles (FCVs). Toyota launched the firstgeneration commercial FCV MIRAI in 2014 and the second copy in 2019. Hyundai also revealed their new hydrogen fuel cell SUV Nexo in 2018. However, to compete with ICE vehicles, PEMFCs in FCVs are challenging in the fields of cost reduction and performance improvement, particularly in the ability to achieve high-power-density operation at high energy efficiency [4].

Figure 1 shows the schematic representation of a PEMFC. The core of the PEMFC is a membrane electrode assembly (MEA), which includes the polymer electrolyte membrane (PEM), catalyst layers (CLs) and gas diffusion layers (GDLs). The MEA is the place for electrochemical reactions including hydrogen oxidation reaction (HOR) at the anode and oxygen reduction reaction (ORR) at the cathode, and also for transfer processes involving multiphase transport, i.e., fuel and oxidant gases from GDLs to CLs, the proton from the anode to the cathode through the PEM and transport of water produced in the cathode [5]. Many studies on PEMFCs for vehicle applications now focus on the R\&D of cost-effective MEAs with low platinum loading and high durability under practical operating conditions [6, 7].

In PEMFCs, the sluggish ORR at the cathode is about 5-6 magnitudes slower than the hydrogen oxidation reaction HOR at the anode, thus causing a large kinetic loss that limits the fuel cell power performance. Therefore, more catalysts are required for the cathode than that for the anode to boost the ORR rate during fuel cell operation. Pt is commonly used at both electrodes and it alone is accountable for more than $40 \%$ of the MEA cost in PEMFCs, delaying mass commercialization of this technology. Lots of efforts have been made to improve the catalyst activity and reduce the Pt loading [3]. The first PEMFC unit used in the Gemini

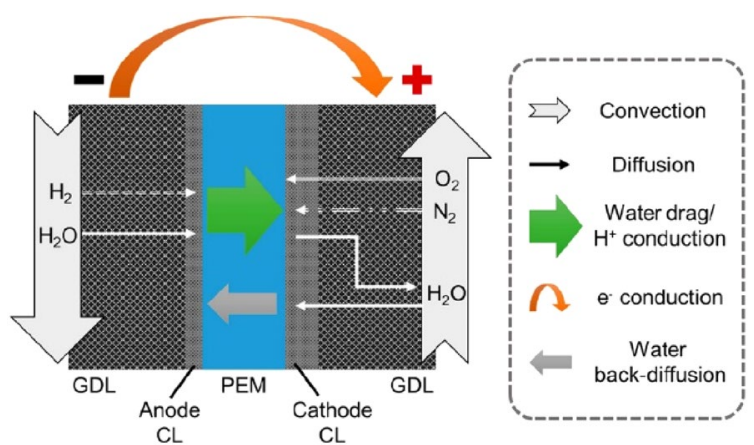

Fig. 1 Flux balance overviews in a simplified PEMFC model [8] aircraft contained a very high catalyst loading $\left(4 \mathrm{mg}_{\mathrm{Pl}} / \mathrm{cm}^{2}\right)$ of unsupported Pt black bound by polytetrafluoroethylene (PTFE) within the electrodes [9]. An important breakthrough in the PEMFC development was achieved by Los Alamos National Laboratory in the 1980s, when the catalyst utilization was significantly improved and the Pt loading was reduced to less than $0.4 \mathrm{mg} / \mathrm{cm}^{2}$ as mostly used today. Those were achieved through extending the triple-phase boundary (TPB) zone in the catalyst layer by introducing proton-conducting ionomer (such as Nafion) and the carbon-supported platinum $(\mathrm{Pt} / \mathrm{C})$ catalyst into the electrodes. Since then, further progresses have been achieved on the improvement of MEAs and the related technologies [10]. For example, Chong et al. [11] prepared highly active ORR catalysts by growing PtCo alloy nanoparticles on CoNC substrate derived from zeolitic imidazolate frameworks. With an ultralow cathode Pt loading of $0.033 \mathrm{mg}_{\mathrm{Pt}} / \mathrm{cm}^{2}$, the MEA achieved a power density of more than $1 \mathrm{~W} / \mathrm{cm}^{2}$ in $\mathrm{H}_{2}$-air fuel cell test under 2 bar $_{\text {abs }}$ of absolute pressure. With $\mathrm{N}$-modified carbon as support for Pt nanoparticle catalysts, Ott et al. [12] designed cathodes showing a power density of $1.39 \mathrm{~W} / \mathrm{cm}^{2}$ at a cathode Pt loading of $0.11 \mathrm{mg}_{\mathrm{Pt}} / \mathrm{cm}^{2}$ (tested at $80{ }^{\circ} \mathrm{C}$ with fully humidified $\mathrm{H}_{2}$ /air at a pressure of $230 \mathrm{kPa}_{\text {abs }}$ ).

Despite tremendous progress achieved with the PEMFC development, there are still many challenges with PEMFCs for their extensive commercialization as FCVs, especially related to the exorbitant cost, low-power performance and poor durability. The cost of an FCV mainly comes from manufacturing and materials. Manufacturing issues, a big part contributing to the current high fuel cell system cost, are amenable to major reduction through economies of scale. Whereas precious metal material costs with the electrocatalysts would not benefit from the economy of scale and even increases at high FCV market penetration [5]. A potential strategy to address this challenge is the development of highpower-performance electrodes with an ultralow Pt loading or Pt-free through the novel catalyst and electrode structure design. Another problem is, along with the development of PEMFCs operating at a large current density (e.g. $>2.5 \mathrm{~A} /$ $\mathrm{cm}^{2}$ ), the cathode catalyst layer undergoes a high water saturation level (i.e., flooding conditions). This thus reduces oxygen mass transport to reaction sites of the catalyst finally resulting in poor fuel cell power performance [13]. Accordingly, various technologies, including 3D mesh flow field plates [14, 15], ordered structure electrodes [16] and hydrophobic GDLs [17], have been investigated to overcome the water management issues.

In this review paper, an overview of the R\&D of PEMFCs with a focus on the cathode catalyst layer is first presented, according to a viewpoint from micro-scale TPB to macro-scale catalyst layer design. Then, research advancements about promoting intrinsic cathodic ORR activities 
in PEMFCs are briefly described. The research efforts on improving mass transport of oxygen and water in the cathode catalyst layer are discussed in detail. Publications reporting MEAs with high-power-density operation are also reviewed. At last, an outlook of the catalyst electrode development for high-power-density operation PEMFCs is given.

\section{Promoting Intrinsic Kinetic Performance of Electrodes}

\subsection{Triple-Phase Boundary (TPB)}

The catalyst layer in fuel cell operation provides continuous channels for electrochemical reactants including protons, electrons and gas (and water in the cathode) [18, 19]. As shown in Fig. 2, the interface (red hollow circle)among the catalyst for conducting electrons, electrolyte phase for conducting protons and pores for transporting gases and/ or water is named as TPB. This concept has been generally used in the study of electrode structure to explain the complex interaction within the CL $[20,21]$.

The electrochemical reaction within the $\mathrm{CL}$ is multiphase. Typically, the catalyst layer is a thin film composed of carbon-supported highly dispersed Pt catalyst nanoparticles and Nafion ionomer additive [22]. The microstructure and composition of the CL have a great influence on its power performance [20, 23-26]. Therefore, many research efforts have been made to optimize the TPB properties within the CL, which can be divided into three strategies: (i) adopting highly active catalysts to promote the intrinsic ORR activity, (ii) introducing novel ionomers to enhance conductivity and (iii) improving catalyst/ionomer interface to extend TPB zones $[27,28]$.

\subsection{ORR Catalysts}

To create efficient triple-phase interfaces to catalyze the ORR, highly active catalysts are essential. In view of the elements, the catalysts are usually divided into two categories as platinum group metal (PGM) and platinum group metal-free (PGM-free)-based materials. Among all the exploited catalysts, pure Pt or Pt-based catalysts are still the best option in terms of automotive applications. The progress and achievements of ORR catalysts in recent decades have been frequently reviewed by researchers based on their activities and durability $[3,29,30]$.

\subsubsection{Pt-based Catalysts}

Pt-based catalysts, including pure platinum, platinum alloys and core-shell platinum structures, are the dominant choices for ORR [31-33]. For single-crystal Pt catalysts, controlling

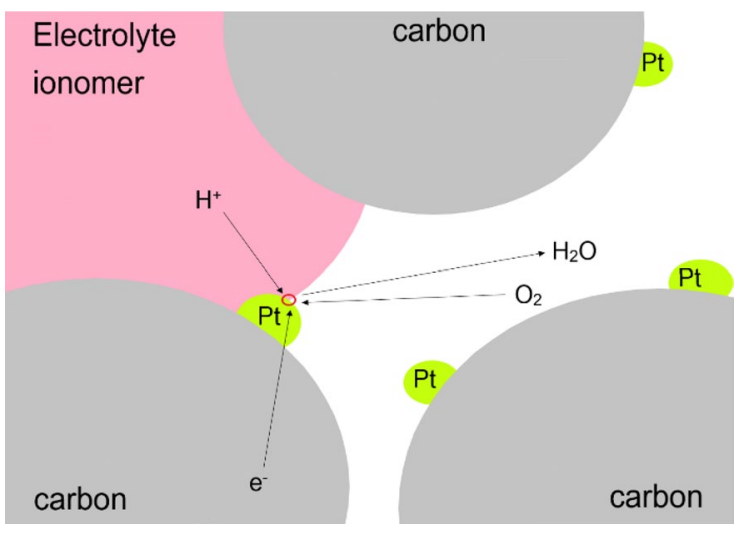

Fig. 2 Schematic illustration of triple-phase boundary in the PEMFC cathode

facets via surface atom rearrangement can tune their catalytic activities [34] because of the structure sensitivity of the ORR to different Pt crystal surfaces [35].

Alloying to form Pt-based bimetallic and trimetallic electrocatalysts is another effective way to improving ORR activity and stability, which is attributed to a shift of the d-band centre caused by electronic structure change on alloy surfaces [36]. Pt monolayer (ML) catalysts, an ideal core-shell structure, can offer a distinctively reduced Pt loading while maintaining considerable possibility for enhancing their activity and stability [37].

PtNi alloy system has been proved to show an excellent performance toward ORR. Stamenkovic et al. [38] demonstrated that $\mathrm{Pt}_{3} \mathrm{Ni}$ (111) surface possessed 90-fold higher activity toward ORR than $\mathrm{Pt} / C$ nanoparticle catalysts for PEMFCs. Besides nanoparticles, many shape-controlled nanostructures were also reported. Chen and co-workers [39] reported $\mathrm{Pt}_{3} \mathrm{Ni}$ nanoframe catalysts exhibiting a factor of 36 and 22 fold enhancement in mass activity and specific activity, respectively, relative to $5 \mathrm{~nm} \mathrm{Pt/C}$ catalysts (TKK) in half-cell electrochemical measurement using the rotating disk electrode (RDE) technique in a liquid electrolyte. Another breakthrough is the achievement of ultrafine jagged Pt nanowires prepared through fully leaching $\mathrm{Ni}$ from $\mathrm{PtNi}$ nanowires [40]. The catalyst demonstrated the highest recorded mass activity of $13.6 \mathrm{~A} / \mathrm{mg}_{\mathrm{Pt}}{ }^{2}$ in the RDE measurement. However, these new shape-controlled catalysts are still in development and a bit distant from the practical applications in PEMFCs for FCVs because of the high difficulties in their scale-up preparation. PtCo alloy catalysts have been demonstrated with similar great ORR activities as $\mathrm{PtNi}$, and they are also the only advanced ORR catalyst that has been successfully used in mass-produced FCVs, i.e., in Toyota Mirai [41]. Compared with other PtM (M represents a transition metal) materials and the widely used $\mathrm{Pt} / \mathrm{C}$ nanoparticles, PtCo alloy catalysts can provide a better balance 
between the activity and durability. In an $\mathrm{H}_{2} / \mathrm{O}_{2}$ MEA test with a cathode $\mathrm{Pt}$ loading of $\sim 0.1 \mathrm{mg} / \mathrm{cm}^{2}, \mathrm{PtCo} / \mathrm{C}$ catalyst demonstrated a high voltage of $0.650 \mathrm{~V}$ at $1.5 \mathrm{~A} / \mathrm{cm}^{2}, 40 \mathrm{mV}$ higher than that of $3 \mathrm{~nm}$ Pt catalysts supported on Vulcan carbon (20 wt\% Pt) [42]. Accelerated stress test (AST) in the MEAs also indicated better stability, and this was further enhanced by annealing at a high temperature (e.g., $600{ }^{\circ} \mathrm{C}$ ) to improve the retention of $\mathrm{Co}$ and further suppressed $\mathrm{Pt}$ dissolution/re-deposition in fuel cell operation. An investigation, conducting on the durability of PEMFC cathodes made of PtCo alloy nanoparticle catalysts with different initial Co contents (34, 20 and $15 \mathrm{~mol} \%$, respectively) revealed that even with significant (27-50\%) Co loss, the specific activity of all PtCo alloy catalysts toward ORR remained higher than $1000 \mu \mathrm{A} / \mathrm{cm}^{2}{ }_{\mathrm{Pt}}$, exceeding $650 \mu \mathrm{A} / \mathrm{cm}^{2}{ }_{\mathrm{Pt}}$ of pure Pt nanoparticles [43]. With commercialized fuel cells in the 2015 Toyota Mirai, MEAs with PtCo catalysts also reached ca. $1.8 \mathrm{~A} / \mathrm{cm}^{2}$ at $0.67 \mathrm{~V}$ (Pt loading at both electrodes $0.33 \mathrm{mg} /$ $\mathrm{cm}^{2}$. Tested in $50 \mathrm{~cm}^{2} \mathrm{H}_{2} /$ air PEMFCs at $94{ }^{\circ} \mathrm{C}$ with $65 / 65 \%$ $\mathrm{RH}, 250 / 250 \mathrm{kPa}_{\mathrm{abs}}$ and stoichiometries of $1.5 / 2$ [44].)

Depositing or forming a thin Pt-based shell (one or several atomic layers) upon the other metal core ( $\mathrm{Pd}, \mathrm{Ru}$, etc.) is a core-shell structure to improve Pt utilization and to achieve remarkable activity and stability. Chung et al. [45] demonstrated that the ORR of such core-shell nanoparticles was largely affected by their subsurface composition rather than the bulk composition. Sasaki et al. [37] reviewed the catalyst achievement in $\mathrm{Pt}$ monolayer on palladium (Pd) nanoparticles for the ORR and described the mechanisms that rationalized their high activity and stability. They recently demonstrated that the ORR activity and stability of the catalysts could be further improved with some novel nanostructured cores by optimizing their surface orientation, composition and morphology $[46,47]$.

\subsubsection{Platinum Group Metal-Free Catalysts}

PGM-free catalysts, including transition metal-based and non-metallic catalysts, are potential candidates to further reduce the cost of PEMFCs in the future. The most promising PGM-free catalysts toward ORR for PEMFC applications are carbonaceous materials doped with nitrogen and one (or more) active 3D-period transition metals (e.g., Fe, $\mathrm{Co}, \mathrm{Mn}, \mathrm{Ni}$ ) [48]. The breakthroughs of $\mathrm{Fe}-\mathrm{N}-\mathrm{C}$ catalysts have been very recently reviewed by Wang et al. [49] with reference to DOE (Department of Energy) standards and targets. However, despite the progress in recent years, the electrocatalytic activity and stability of PGM-free catalysts are still not expected to meet the practical demands in a short time [50].

In 2006, a breakthrough on PGM-free FeNC catalysts was achieved by Dodelet et al. [51] who found the crucial role of micropores on carbon substrates for hosting the atomic active sites. Zelenay and co-workers [52] thus reported a considerable activity of $0.016 \mathrm{~A} / \mathrm{cm}^{2}$ at $0.9 \mathrm{~V}_{\mathrm{iR} \text {-free }}$ under the DOE testing protocol, using a hierarchical porous FeNC catalyst $((\mathrm{CM}+\mathrm{PANI})-\mathrm{Fe}-\mathrm{C})$. Recently, many researchers have reported on the three-dimensional (3D) architecture of PGM-free catalysts to enhance mass transfer properties and catalyst utilization ratio to achieve reasonable power performance in PEMFCs. Li and co-workers [53] reported controlled 3D fibrous FeNC cathodes engineered via a facile electrospinning approach. The cathode achieved $0.3 \mathrm{~A} / \mathrm{cm}^{2}$ at $0.6 \mathrm{~V}$ in $\mathrm{H}_{2}$ /air fuel cell test. $\mathrm{Wu}$ and co-workers [54] reported a novel imidazole-based ionic liquid and used it to prepare an $\mathrm{N}$ and $\mathrm{S}$ co-doped metal-free catalyst with 3D-ordered microstructures. Wang et al. [55] reported a newly designed $\mathrm{FeO}_{\mathrm{x}} @$ graphitic carbon core-shell structured nanoparticles implanted in an $\mathrm{N}$-doped carbon matrix. With ordered and mesoporous structure, the $\mathrm{FeO}_{\mathrm{x}} @ \mathrm{GC}$ cathode with a catalyst loading of $3 \mathrm{mg} / \mathrm{cm}^{2}$ recorded a specific power density of $350 \mathrm{~W} / \mathrm{g}^{1}$ in $\mathrm{H}_{2} / \mathrm{O}_{2}$ PEMFC test. In consideration of improving the catalyst electrode durability, hybrid $\mathrm{Pt} / \mathrm{FeNC}$ with an ultralow loading of Pt have been demonstrated and synergy effects were reported [56, 57]. STEM (Scanning transmission electron microscope) analysis revealed a stabilization of the Fe-oxide by subsurface Pt (111) and they attributed the enhanced stability and ORR activity to the electron-tunnelling effect from Pt (111) through the ultrathin Fe-oxide shell.

In 2017, Ballard Power Systems announced the commercialization of the world's first PEMFC product to utilize a PGM-free catalyst at the cathode (FCgen-micro) [58, 59]. However, the PGM-free catalyst is not widely used now.

\subsection{Extending TPB Zones by lonomers}

Introducing proton-conducting ionomer into electrodes brought about a great breakthrough in the PEMFC development in the 1980s, which greatly extended the TPB zone and improved electrode power performance by boosting the Pt utilization. In the CL, the ionomers act as: (i) proton conductors to expand the electrochemically active region into the bulk catalyst layer, (ii) binding materials to impart mechanical stability and (iii) hydrophilic agents to help retain moisture and prevent membrane dehydration [60]. The distribution and content of ionomer can directly influence the protonic and electronic conductivity of the CL. Particularly, when PEMFC is operating at a large current density exceeding $1.5 \mathrm{~A} / \mathrm{cm}^{2}$, the ionomer distribution becomes more important because of the mass transport of $\mathrm{H}^{+}$and $\mathrm{O}_{2}$ through the ionomer film on the catalyst surface. 


\subsubsection{Perfluorinated Sulfonic-Acid (PFSA) lonomer}

Conventionally, Nafion ionomer is mixed with $\mathrm{Pt} / \mathrm{C}$ to create Pt/ionomer/C TPB. Nafion, a trademark of DuPont company, is a perfluorinated sulfonic-acid (PFSA) ionic polymer containing a highly hydrophobic PTFE backbone and a strong hydrophilic sulfonic acid side chain. PFSA ionomers are members of a class of ion-conductive polymers known for their remarkable ionic conductivity and their chemical and mechanical stability. The characteristics of phase separation and proton transport of PFSA ionomers are determined by their chemical structure and composition [61]. Many PFSA ionomers have been developed, and Fig. 3 shows several commercial types with their key chemical structural parameters. PFSA ionomers are usually categorized according to their side-chain length or equivalent weight (EW). For example, Aquivion (formerly Dow SSC) PFSAs are commonly classified as short-side-chain (SSC) PFSAs, while Nafion is considered as a long-side-chain (LSC) PFSA. The conductivity of PFSA ionomers increases as the EW is lowered.

Traditionally, PEMFCs utilize LSC PFSA ionomer (i.e., Nafion) and many studies have been reported on the structure-power performance relationships of Nafion-based catalyst layers. The investigation shows that, with the increase in the ionomer loading, the ionic conduction efficiency increases, while the electronic conduction efficiency diminishes, both in an exponential fashion [62]. For an ultralow catalyst loading electrode operating at a large current density, the requirements for proton-conducting and mass transport are very high, thus optimal use of ionomer is of high importance to balance the porosity, proton and water transport in the cathode CL.

The use of SSC ionomer in the catalyst layer has been demonstrated with some advantages. Compared with the

PFSA ionomers: general chemical structure

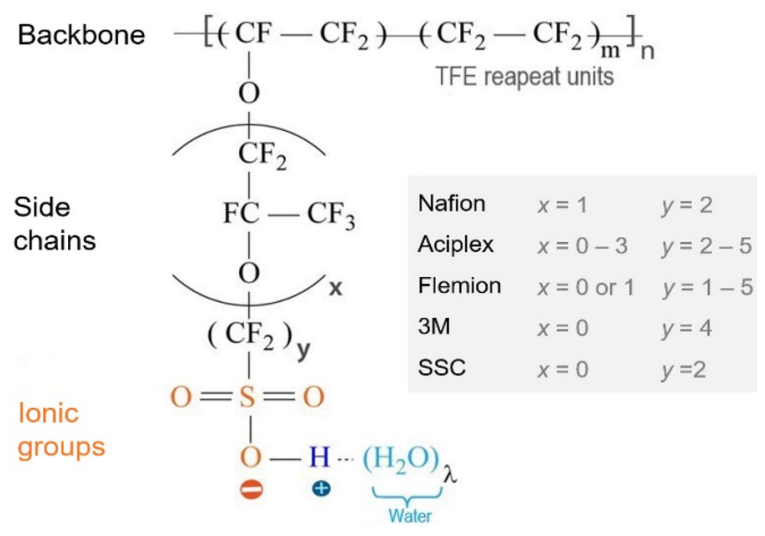

Fig. 3 General chemical formula for commercial PFSA ionomers, shown with key chemical structural parameters [61]
LSC ionomer, the low EW SSC ionomer has more sulfonic groups that can improve its proton conductivity, and the ionomer distribution and coverage on the catalyst surface in the CL [63]. Garsany et al. [64] found that the SSC ionomer imparted low proton transport resistances, reducing charge transfer resistance within the cathode at near $0.60 \mathrm{~V}$ and mass transport resistance at $0.40 \mathrm{~V}$. The improved electrode performance was attributed to the superior proton conductivity of the SSC ionomer and higher micropore volume. The latter can be more effective for evaporating water to the gas phase and improve the availability of both catalyst sites for charge transfer and mesopores for gas transport.

\subsubsection{Other Proton Conductors}

PFSA ionomers have several drawbacks, and the most impressive ones are their high synthesis cost because of the complex fluorine chemistry and requirement of high humidity resulting in a mandatory low fuel cell operating temperature [65]. Several solutions have been developed with low fluorinated or even no-fluorinated SSC ionomer polymers to substitute PFSA ionomers.

A low-fluorinated ionomer is beneficial to reduce cost. Ebenezer et al. [66] used low-fluorinated and low-cost crosslinked PVA/SSA ionic polymer as hydrocarbon ionomer to prepare CLs. They identified that the performance of this ionomer was as good as Nafion in the anode catalyst layer and the MEA was less sensitive to the relative humidity of reactant gases. Yang et al. [67] reported a bottom-up design of Pt electrocatalysts with a homogeneous Nafion-free ionomer layer, in which Pt nanoparticles were deposited on CNTs after sequentially wrapping with polybenzimidazole (PBI) and protonic conductive end-capped hyperbranched sulfonated macromolecules (E-HBM) (CNT/PBI/E-HBM/ $\mathrm{Pt}$ ). The base-acid interaction between PBI and E-HBM enabled homogeneous coating of E-HBM on CNTs, leading to improved Pt stability and electrode durability. The MEA fabricated from the CNT/PBI/E-HBM/Pt cathode showed a higher power density of $704 \mathrm{Mw} / \mathrm{cm}^{2}$, compared to $603 \mathrm{Mw} /$ $\mathrm{cm}^{2}$ with Nafion ionomer.

Dru et al. [68] proposed a universal nonfluorinated solution to build the catalyst layer. The fluorine-free ionomer sodium polystyrenesulfonate (PSSNa) was grafted directly at the surface of carbon-supported Pt nanoparticles for the transposition of the TPB at the molecular level. Figure 4 shows the synthesis process of the Pt-PSSNa/C nanocomposite material. The results show that both the chain length and the number of grafted polymers played a big role in the catalyst activities and stability in fuel cell operation. A low grafting density and high degree polymerization led to better performance, exhibited the same power density but better durability than that with Nafion ionomer (60 cf. $90 \mu \mathrm{V} \mathrm{h}^{-1}$ ) in $\mathrm{H}_{2} / \mathrm{O}_{2}$ PEMFC test. 
Another strategy recently reported combines ionic liquids (ILs) with Nafion ionomer to extend proton-conducting network in CLs. Some ILs possess excellent oxygen solubility and diffusivity, although not as good as Nafion ionomer, they can penetrate the small pores that cannot be reached by the large ionomer cluster thus enhancing catalyst utilization ratio. Li et al. [69] introduced a sulfonated poly(ionic liquid) block copolymer (SPILBCP) as an additive to Nafion ionomer in the catalyst layer. From an electrode structure point of view illustrated in Fig. 5, LSC Nafion ionomer helps bridging vacancies between isolated SPILBCP aggregates under both high and low relative humidity, forming highly connected ionomer networks and facilitating proton transport in the catalyst layer, increasing Pt utilization. The use of superhydrophobic ILs can further help repel the produced water and reduce the surface oxidation of catalysts. For examples, ILs include [MTBD] [beti] (7-methyl-1,5,7triazabicyclo [4.4.0]dec-5-ene bis(perfluoroethylsulfonyl) imide), $\left[\mathrm{C}_{4} \mathrm{C}_{1} \mathrm{im}\right]$ [ $\left.\mathrm{NTf}_{2}\right]$ (1-butyl-3-methylimidazolium bis(trifluoromethanesulfonyl)imide) and [BMIM] $\left[\mathrm{NTf}_{2}\right]$ (1-butyl-3-methylimidazolium bis(trifluoromethylsulfonyl) imide) have been used to modify Pt-based $\mathrm{PtNi} / \mathrm{C}$ and $\mathrm{Pt} / \mathrm{C}$, and PGM-free ZnCoNC catalysts for PEMFC application [70-72]. Importantly, ILs presenting at the catalyst interface can act to prevent the specific adsorption of sulfonate groups of Nafion on Pt surfaces, negating the detrimental impact of the ionomer on reaction rates, specifically for ORR, thus improving PEMFC high current density performance [73]. Improved power performance was successfully demonstrated in either $\mathrm{H}_{2} / \mathrm{O}_{2}$ or $\mathrm{H}_{2}$ /air MEA test. However, the durability of this approach is still not clear in long-term fuel cell operation, in particular considering the severe higher operating temperature compared to the electrochemical measurement in a liquid electrolyte where the outstanding stability of this IL modification has been shown.

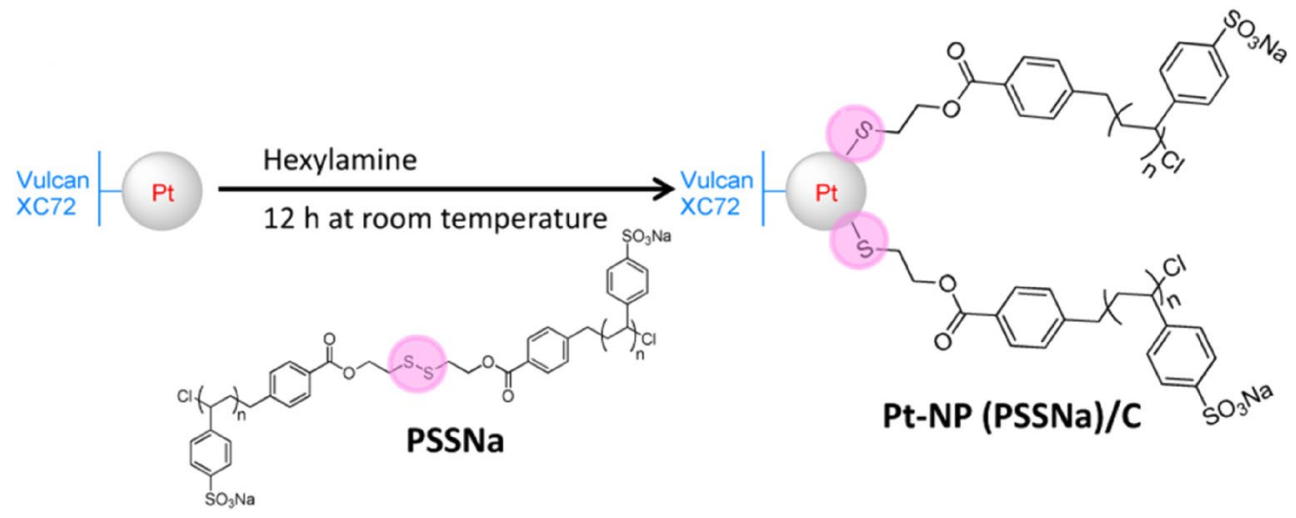

Fig. 4 Pt-PSSNa/C nanocomposite material synthesis process [68]

Fig. 5 Proposed microstructure of 0.6SPILBCP:C and 0.3SPILBCP:C + 0.3Nafion:C electrodes depicting the effect of ionomer distribution on $\mathrm{Pt}$ utilization under dry and wet operating conditions [69]

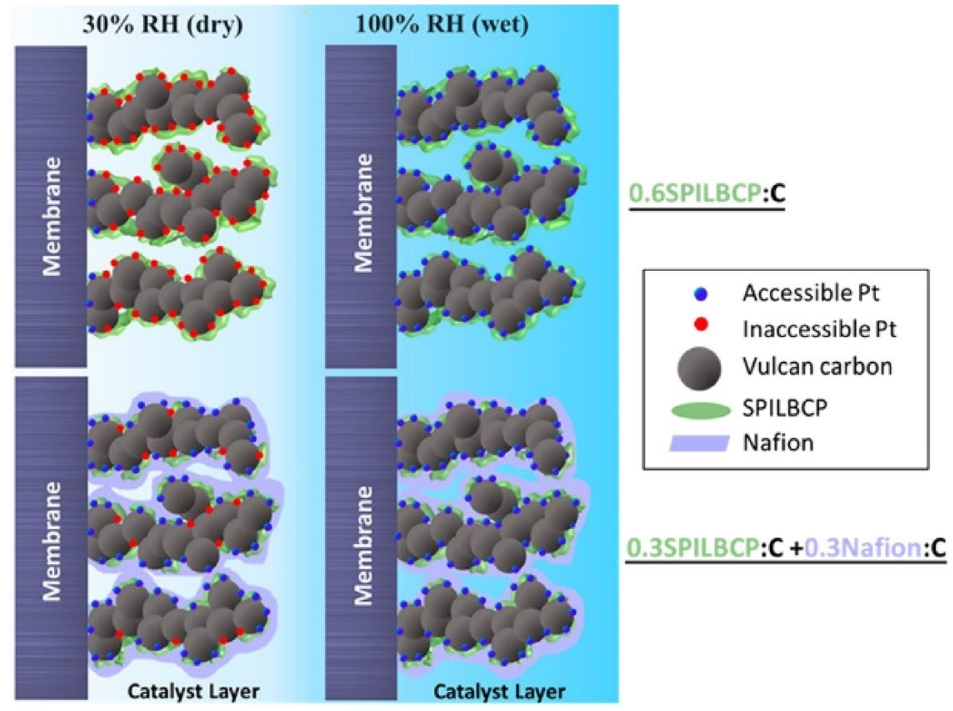




\subsection{Improving lonomer/Catalyst Interface}

In PEMFC catalyst layers, ionomers are found as nanometer-thick "thin films" binding the catalyst particles together, facilitating proton transport through the layer and gas/water transport to and from the catalytic sites, respectively [61].

Homogeneous distribution of ionomer on catalyst surface is essential to achieve high-power performance and sustained electrode stability, i.e., high ORR kinetics and excellent mass transport properties. Typically, the catalyst layer is fabricated starting from catalyst ink, which is prepared by mixing carbon-supported Pt nanoparticle catalysts (i.e., $\mathrm{Pt} / \mathrm{C})$, Nafion ionomer, isopropyl alcohol, and water [74]. After thoroughly mixing the catalyst ink to ensure a homogenous mixture, it is sprayed or coated onto the microporous layer of a GDL for the case of the gas diffusion electrode (GDE), or the membrane for the case of the catalyst coated membrane (CCM) [75]. In improving the ionomer/catalyst interface, the catalyst support structure and surface properties [12, 63], ionomer/catalyst ratio [76] and catalyst ink dispersing methodology [77] all show great influence on the electrode power performance.

The catalyst/ionomer interfacial structure is largely determined by the interaction between $\mathrm{Pt}$ and the ionomer side chains, and the density of ionomers is higher in areas of the catalyst surface containing Pt because of the better wettability of Pt surface than that of the carbon support [63]. However, the strong adsorption of the sulfonate group of the PFSA ionomer is poison for the Pt surface and reduces the catalyst activity during fuel cell operation. Yamada et al. [78] used dopamine (DA) to protect the Pt catalyst surface from poisoning. The coverage of the adsorbed sulfonates from the ionomer on the Pt surface was decreased with the increasing DA amount. Improved mass activity and durability were achieved. However, this method cannot address the oxygen transport issue at the interface between $\mathrm{Pt}$ and ionomer. The power performance at a high current density operation was deteriorated by the modification. Zhou et al. [79] have explored a thin porous layer derived from Nafion formed on the surface of $\mathrm{Pt} / \mathrm{C}$ catalyst to create a shell to reduce the ionomer poisoning and improve the oxygen accessibility. The experimental results demonstrated a very thin coating that helped to separate the Nafion ionomer and Pt particles in the catalysts exhibiting enhanced fuel cell performance.

Breakthrough in boosting the PEMFC power performance has recently been achieved through tuning structure and surface properties of catalyst support to improve the interaction between ionomer and catalysts. Yarlagadda et al. [44] demonstrated that porous carbons with a preferred pore size of 4-7 nm endowed catalysts with both excellent ORR activities and transport properties (Fig. 6). Catalysts supported on solid carbon have good transport properties, but are easily poisoned by the ionomer. In contrast, for catalysts supported on porous carbon, the interior catalyst particles within pores have limited access to protons and reactant gases. And, this effect will become more prominent for an electrode with an ultralow Pt loading operated at a large current density. Compared to solid Vulcan and porous Ketjenblack support, PtCo supported on porous carbon with access pores showed a boosted power performance of $14.3 \mathrm{~kW} / \mathrm{g}_{\mathrm{PGM}}$ with a cathode Pt loading of $0.063 \mathrm{mg}_{\mathrm{Pt}} / \mathrm{cm}^{2}$ (tested at $94{ }^{\circ} \mathrm{C}$ with a $50 \mathrm{~cm}^{2} \mathrm{MEA}$ under $\mathrm{H}_{2} /$ air at $65 / 65 \% \mathrm{RH}, 250 / 250 \mathrm{kPa}_{\text {abs }}$ and stoichiometries of $1.5 / 2$ at the anode/cathode, respectively). Recent achievements revealed that the ionomer distribution on Pt/C surface can be tailored by modifying carbon support surface. Orfanidi et al. [80] functionalized carbon support with $-\mathrm{NH}_{\mathrm{x}}$ groups. The coulombic interaction between ${ }_{-} \mathrm{NH}_{\mathrm{x}}$ groups and negatively charged $-\mathrm{SO}_{3}{ }^{-}$of the ionomer side-chains promoted the homogeneous distribution of the ionomer on $\mathrm{Pt} / \mathrm{C}$ catalyst surface, although the stability of $-\mathrm{NH}_{\mathrm{x}}$ groups to sustain the suppression of local oxygen transport losses is still an issue. As an advancement, N-modified ketjenblack has been recently studied by Ott et al. [12] The surface N-modification of carbon support with tailored porosity imparted controlled deposition of Pt nanoparticles in or close to carbon pores, and also a uniform coverage of ionomer on the support surface. This also led to a lower degree of Pt surface poisoning by ionomer. With the new catalyst design, single cells with a cathode Pt loading of $0.11 \mathrm{mg}_{\mathrm{Pt}} / \mathrm{cm}^{2}$ displayed a large power density of $1.39 \mathrm{~W} /$ $\mathrm{cm}^{2}$ and high stability under voltage cycling $\left(1.4 \mathrm{~cm}^{2}\right.$ MEAs, tested at $80{ }^{\circ} \mathrm{C}$ with fully humidified $\mathrm{H}_{2} /$ air at a pressure of $230 \mathrm{kPa}_{\text {abs }}$ and constant flow of $1000 / 2000$ normal cubic centimeters).

The effect of sonication degree on the preparation of catalyst ink was studied using in-situ X-ray scattering [77]. A

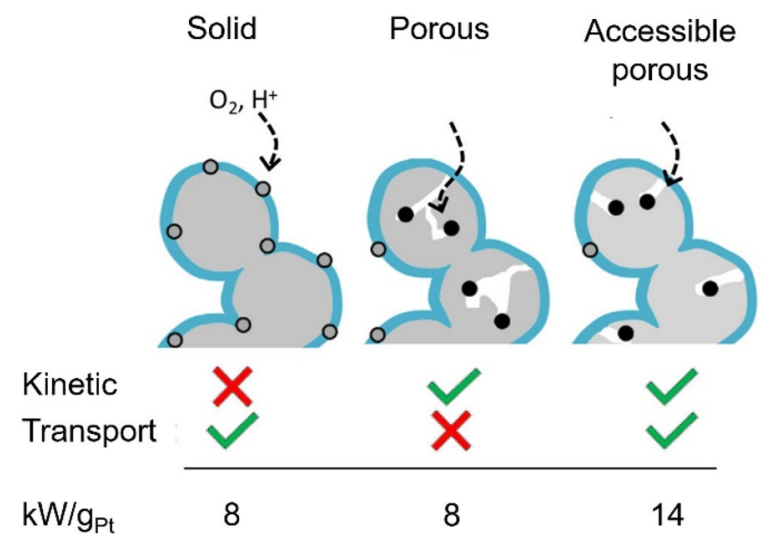

Fig. 6 Comparison of ORR kinetic and transport $\left(\mathrm{O}_{2}\right.$ and proton) characteristics of CLs made from solid, porous and accessible porous carbon support (gray). Small black and gray circles represent relatively high and low activity Pt particles, respectively, due to ionomer (blue) adsorption [44] 
combination of tip and bath sonication was demonstrated as an efficient way to break down carbon agglomerates into small aggregates without detaching the supported $\mathrm{Pt}$ nanoparticles. Three dispersed states were proposed and are shown in Fig. 7. With insufficient sonication, the primary agglomerates are not broken; thus, the interior Pt nanoparticles are not accessible for proton conducting ionomer. In contrast, excessive sonication led to Pt nanoparticle detaching from the carbon support. For the case of appropriate sonication, the ionomer is uniformly distributed on the broken agglomerates, resulting in high catalyst utilization as well as low mass transport resistance. An investigation on dynamic light scattering (DLS) also suggested that larger agglomerates might help the formation of holes in the CL for gas diffusion and water removal, with the optimum size found to be around 400-800 nm [19]. Therefore, good control of the dispersion process is essential to achieve high electrode power performance.

The influences and mechanisms of the solvents mixed into catalyst ink were also investigated. The mixture of PFSA ionomer and organic solvents have three states: solution $(\varepsilon>10)$, colloid $(3<\varepsilon<10)$ and precipitate $(\varepsilon<3)$, according to the dielectric constant $\varepsilon$ of organic solvents, and the electrode prepared by a colloidal method usually shows better results [81]. Isopropyl alcohol (IPA) is the most commonly used solvent. Other solvents, such as glycerol [82], $\mathrm{N}$-methyl-2-pyrrolicone (NMP) [83] and polyethylene glycol (PEG) [84] have been explored to increase the catalyst-water-ionomer interface. Kim et al. [85] investigated the mobility of the polymeric chains in Nafion ionomer dispersion in IPA, dimethyl sulfoxide (DMSO) and NMP. It was found the solvents with high main-chain mobility led to a more intimate contact at the TPB thus a better electrochemical property, which was mainly attributed to the strong interaction between the solvent molecule and Nafion ionomer. On the effects of the $\mathrm{H}_{2} \mathrm{O}$ content, there are conflict opinions. It was considered that increasing the water content resulted in increased carbon aggregation and low ionomer coverage with a large thickness [86]. It was also demonstrated that the ionomer aggregate size in the water-rich inks decreased resulting in enhanced ionomer/Pt interaction [87]. The reduced ionomer aggregation improved oxygen transport resistance through the ionomer film, while the increased adsorption led to enlarged resistance at the ionomer/Pt interface.

\section{Microstructure of Catalyst Layers}

The microstructure of the CL determines its mass transport characteristics, which in the cathode include both oxygen supplying and water removal.

\subsection{Porous Structure within Catalyst Layers}

The catalyst layer, usually made of Pt/C catalysts and ionomer, is a porous medium with randomly distributed hydrophobic and hydrophilic sites. Within the cathode, the ORR occurs at the TPB zone in the CL [88]. To complete fuel cell reactions, transport networks are necessary within the $\mathrm{CL}$ for transferring reactants $\left(\mathrm{O}_{2}\right.$ /air at the cathode $)$, electrons and protons to catalytic reaction sites and repelling generated water out of the CL [89]. According to a pore-scale CL model based on the lattice Boltzmann method (LBM) to simulate reactive transport processes by Hou et al. [76], an ideal structure design, which simultaneously ensures a large active catalyst area and extremely low transport losses, can enhance the power performance by $50 \%$.

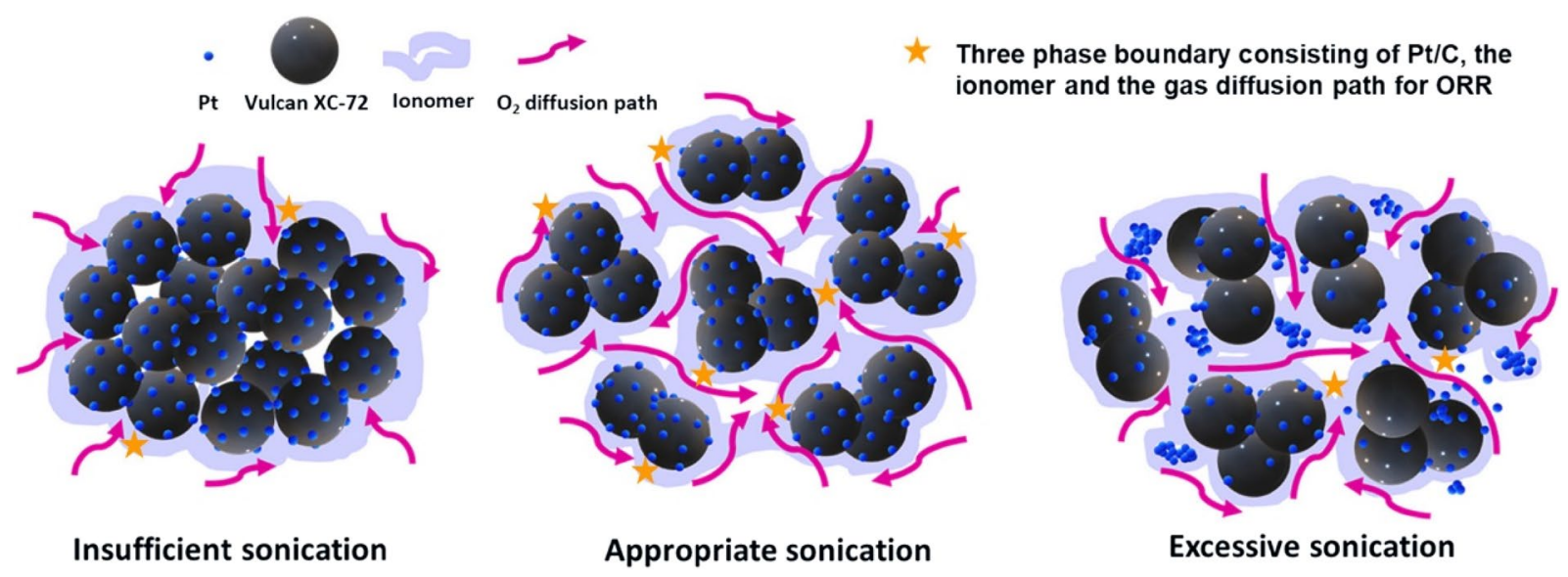

Fig. 7 Proposed structure of $\mathrm{Pt} / \mathrm{C}$ and Nafion ionomer with different ink processing procedures [77] 
A highly porous structure is essential for the CL, but the negative aspect is that electronic and ionic conduction efficiency decreases linearly with the porosity [62]. To control the geometrical parameters of pores, pore size distribution and porosity can be tailored by porosity enhancers, "pore-forming" agent [90, 91], carbon black support [92] and catalyst ink composition (ionomer to carbon ratio, etc.) $[93,94]$. A new concept of in-situ pore generation to reduce water flooding in the cathode catalyst layer (CCL) based on sulfonated polyether ether ketone Sulfonated polyether ether ketone (SPEEK) has been proposed by introducing water-soluble PEG as a pore generator. During the fuel cell operation, PEG was dissolved in water produced and removed to form controlled pores [91]. Suzuki et al. [93] reported that the ionomer content was the determinative factor of CL void volume. Taghiabadi et al. [95] evaluated the performance of different void volumes and found a $20.8 \%$ CCL porosity leading to the best MEA performance. Sassin et al. [96] examined the interplay between the porosity and thickness of the CCL on its mass transport limitations in PEMFCs. They showed that the highest power performance was delivered by a 7.5- $\mu \mathrm{m}$-thick CCL because of an optimal balance between solid and void networks.

The interplay of wettability and pore sizes influences water distribution within the CL, microporous layer (MPL) of the GDL and specifically their interface [97]. Thereby, in addition to the porosity, hydrophobicity and hydrophilicity feature of the CCL have been investigated as another way to improve its mass transport characteristics for enhancing MEA performance [98]. While it was found that an anode with hydrophilic property helped improve the fuel cell power performance in low humidity operation, excessive hydrophilicity in the cathode caused water flooding. Oh et al. [99] and Li et al. [100] introduced poly (vinylidene fluoride-co-hexafluoropropylene) and dimethyl, respectively, to increase the hydrophobicity of the CCL, improving both oxygen diffusion and water management. Chi and coworkers [101] utilized CNTs as porosity enhancers and PTFE as a surface modulating agent to develop MEAs possessing highly porous CCL structures with great hydrophobicity. Figure 8 shows scanning electronic microscopy (SEM) images of the surface and cross-sectional structure of the MEAs with different CCL compositions. At 0.7 and $0.6 \mathrm{~V}$, the MEA exhibited larger current densities of 1 and $1.55 \mathrm{~A} / \mathrm{cm}^{2}$, respectively, compared to 0.75 and $1.2 \mathrm{~A} / \mathrm{cm}^{2}$ of the one without CNTs and PTFE. However, too many hydrophobic materials (e.g., PTFE) also block the pores leading to high mass transport resistance in the CCL. Thereby, a balance between the large porosity and high hydrophobicity can be highly beneficial for improving the fuel cell power performance.

\subsection{Diffusion Principles in Catalyst Layers}

The oxygen diffusion in the CL includes three parts: molecular diffusion, Knudsen diffusion and permeation through the ionomer film surrounding the catalyst agglomerates. For a CCL with an ultralow catalyst loading, the contribution of oxygen penetrating through the ionomer film is a major part of the total mass transport resistance [102]. This resistance can be significantly reduced by improving the ionomer distribution to form a homogeneous thin layer on the catalyst surface. Potential strategies include modifying the catalyst support (e.g., $\mathrm{NH}_{3}$ or $\mathrm{N}$ - groups functionalizing carbon support), using SSC ionomer or even combining with ILs, [12, 64, 69, 80] which have been discussed in Sect. 2. The diffusion mechanism in the gas phase of the CL can be split into

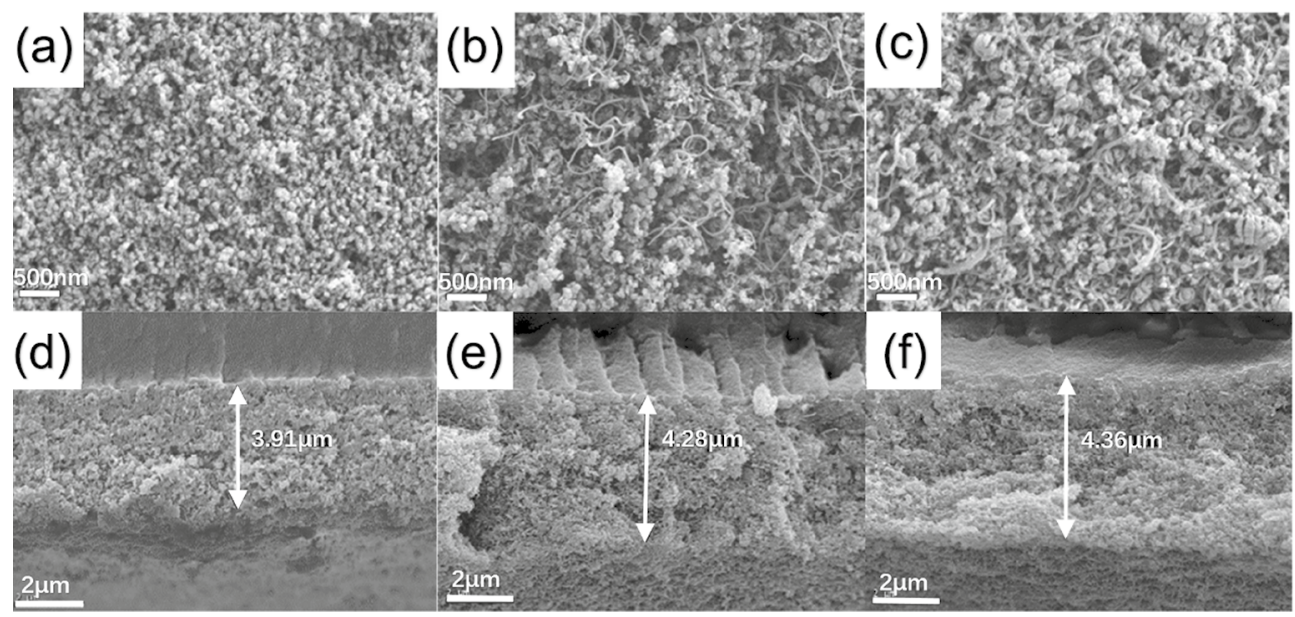

Fig. 8 SEM images of the surface and cross-sectional structure of: a, d MEA-0CNT-0PT (without CNTs or PTFE added); b, e MEA-15CNTOPT (with only $15 \mathrm{wt} \%$ CNTs added); and c, f MEA-15CNT-30PT(with $15 \mathrm{wt} \%$ CNTs and 30\% PTFE add) [101] 
Knudsen diffusion by collisions between the molecules and pore walls, and bulk (or molecular) diffusion occurring with collisions between the molecules [103].

Catalyst layers with the same porosity can have very different tortuosity and diffusivity. The tortuosity factor of CLs is much larger than the generally well-known tortuosity factor of porous media, which is attributed to the existence of isolated pores and non-spherical dead-end pores. The existence of isolated pores substantially affects gas diffusion in the $\mathrm{CL}$, while the formation of non-spherical dead-end pores can lead to a higher tortuosity factor [104].

Oxygen effective diffusivity, $D^{\text {eff }}$, is defined as a function of the porosity $\varepsilon$, the tortuosity $\tau$ and oxygen diffusivity in the pore scale $D$, which can be expressed by:

$D^{\text {eff }}=(\varepsilon / \tau) D$

Oxygen diffusivity $D$ in the pore scale can be approximated by Bosanquet's formula as the following:

$D=\left[\left(D^{\mathrm{Kn}}\right)^{-1}+\left(D^{\mathrm{bulk}}\right)^{-1}\right]^{-1}$

where $D^{\mathrm{Kn}}$ and $D^{\text {bulk }}$ represent Knudsen diffusivity and bulk diffusivity, respectively.

The oxygen diffusion in the gas phase of the CL is dominated by the Knudsen effect [105]. Isolated pores resulted in a substantial increase of the tortuosity factor $\tau$ and thus a decrease of the effective gas diffusivity $D^{\text {eff }}$. The dead-end pores can be another factor affecting $D^{\mathrm{eff}}$. The isolated pores and the dead-end pores were formed by ionomer deposition onto Pt/C agglomerates. And support materials would result in different tortuosity within the CL [104]. Within a CL with an ultralow catalyst loading, the influence of Knudsen diffusion becomes less important [102]. However, under highcurrent-density operation conditions, the large amount of liquid water generated at the cathode can significantly reduce the effective porosity, and flooding is severe which limits oxygen transport. On the contrary to the flooding, efficient retention of the liquid water generated from the cathode is also preferred in some cases. A strategy can be used to alleviate the operation dependence on external humidification of air feed because the commonly used PFSA ionomer requires to be kept humid to attain reliable proton conductivity [103]. Therefore, electrode structure with a good balance of porosity, tortuosity and water management (i.e., hydrophilic and hydrophobic feature) is still highly preferred for electrodes with a low catalyst loading, e.g., CLs with 3D-ordered structure.

\subsection{Catalyst Layers with 3D-Ordered Structure}

The distribution of pores, proton conductors and electronic conductors is random in conventional $\mathrm{Pt} / \mathrm{C}$ nanoparticle electrodes in PEMFCs. This results in a very low catalyst utilization (20-30\%) and high oxygen transport resistance at large-current-density operations. The development of 3D-ordered CLs from aligned 1D nanostructures is regarded as the most promising approach to address this challenge and boost fuel cell performance. With well-designed porosities, the electrodes with aligned 1D nanostructures can provide a super-high utilization percentage of active sites exposed with significantly improved mass transfer performance. Middelman et al. [106] firstly came up with the concept of the ideal electrode structure, in which all electronic conductor, proton conductor and pores are oriented along with the corresponding transport directions. A few reports and reviews have been published on 3D-ordered electrodes for PEMFCs, which can be roughly divided into catalyst support and catalyst-based ordered structures [107, 108].

\subsubsection{Ordered Catalyst Support Structure}

The aligned catalyst support materials reported for fabricating 3D-ordered electrodes mainly include polymer whiskers and nanowires, carbon nanotubes and fibres, and metal oxide nanotubes and nanorods. Nanostructured thin film (NSTF) or nanoparticle catalysts are usually deposited on the aligned support surface using physical sputtering techniques. A typical preparation process of an ordered electrode is shown in Fig. 9.

One significant development of this type of 3D-ordered electrodes is the NSTF catalyst layer from the $3 \mathrm{M}$ Company. This technology has been mentioned in many review papers although there're still some big challenges faced by commercialization after more than 20 years of development. The NSTF electrode is composed of arrays of oriented short (less than $1 \mu \mathrm{m}$ in length) crystalline organic-pigment whiskers, fully covered by a thin Pt or Pt-based alloy catalyst layer deposited by a vacuum sputter technique. The open ordered structure and small thickness of the CL enable improved oxygen mass transport and better accessibility of the $\mathrm{Pt}$ active sites, along with the proton transport occurring through the water trapped within the catalyst nanostructures, finally leading to superior power performance $[50,110]$. However, low electrochemical active specific area (ECSA) and flooding issues limit the real application of this NSTF catalyst [111]. As an alternative to organic pigment whiskers, polypyrrole (PPy) and polyaniline (PAni) nanowire arrays have also been reported for this application in PEMFCs [112-114].

Compared with 1D polymer supports, 1D carbonaceous materials possess better electrical conductivity and also excellent stability. Tian et al. [109] prepared electrodes with vertically aligned carbon nanotubes (VACNTs) supported Pt nanoparticles (Fig. 9). The best electrode power performance was recorded with an ultra-low Pt loading 

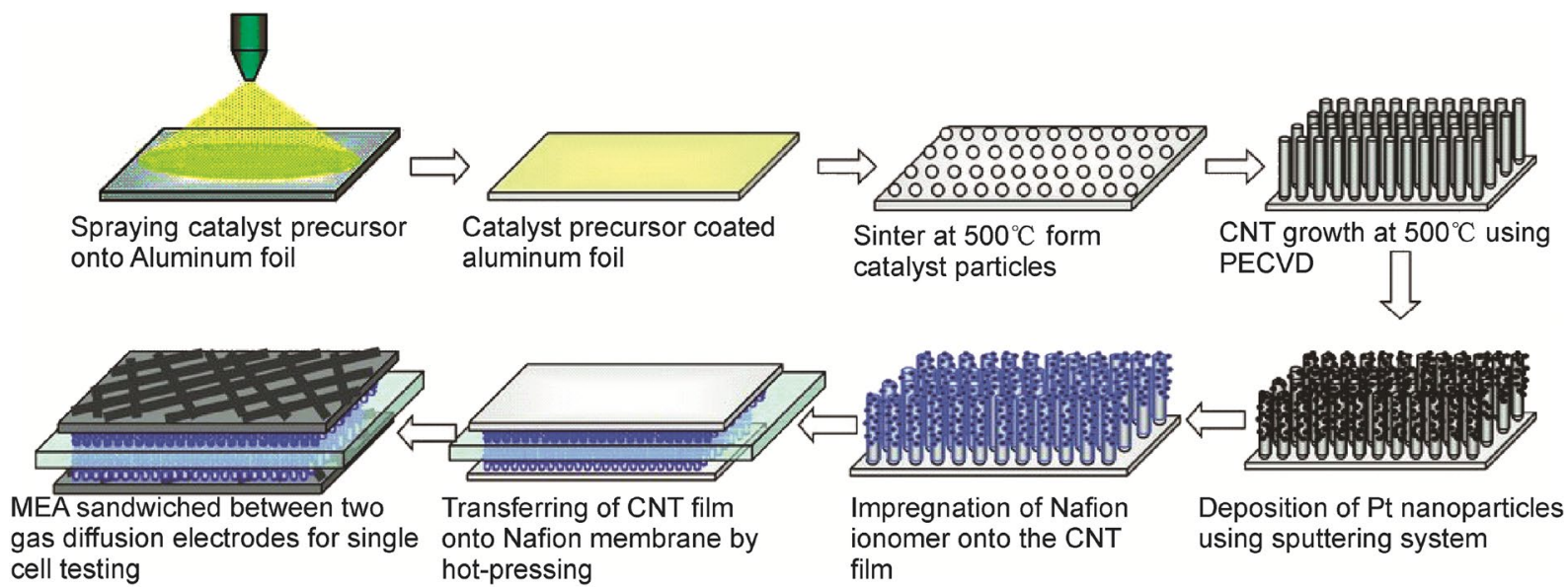

Fig. 9 Schematic illustration of the synthesis of Pt catalysts on vertically aligned carbon nanotube (VACNTs) and fabrication of the membrane electrode assembly [109]

of $0.035 \mathrm{mg} / \mathrm{cm}^{2}$, which showed a comparable power density to that of a commercial $\mathrm{Pt} / \mathrm{C}(40 \mathrm{wt} \% \mathrm{Pt} / \mathrm{C}$ from Johnson Matthey, JM) electrode with $0.4 \mathrm{mg}_{\mathrm{Pt}} / \mathrm{cm}^{2}$. Meng et al. [16] reported a novel bi-functional layer consisting of VACNTs and PtCo nanoparticles catalysts ( $\mathrm{PtCo} /$ VACNTs) with well-aligned channels, which greatly facilitated fast transport of oxygen, electron, water and proton inside the CL. Moreover, as shown in Fig. 10, by precise manipulation of the surface hydrophilic-hydrophobic and pore structure of the PtCo/VACNTs, the Janus-type surface coupled with high porosity makes it suitable for water management and gas diffusion. The structure also successfully eliminated the commonly used MPL layer. The bi-functional $\mathrm{PtCo} / \mathrm{VACNT}$ cathode with an ultralow Pt loading of $0.065 \mathrm{mg}_{\mathrm{Pt}} / \mathrm{cm}^{2}$ showed a higher peak power density of $1.41 \mathrm{~W} / \mathrm{cm}^{2}$ compared to $1.31 \mathrm{~W} / \mathrm{cm}^{2}$ of the one with commercial $\mathrm{Pt} / \mathrm{C}$ catalysts (JM, $40 \mathrm{wt} \%$ ) at a loading of $0.4 \mathrm{mg}_{\mathrm{Pt}} / \mathrm{cm}^{2}$. However, by the physical sputtering technique, there is a big challenge to achieve a high catalyst loading. Thereby, the optimal power density recorded is usually only comparable or slightly higher than the $\mathrm{Pt} / \mathrm{C}$ electrodes with a medium catalyst loading. Although the ultralow loading can reduce the catalyst cost, there are still big challenges to realize a real high-power-density operation. In view of this drawback, Du's group [115] designed CLs from 1D Pt catalysts deposited on VACNTs by a facile wet chemical method. With a catalyst loading of $0.19 \mathrm{mg}_{\mathrm{Pt}} /$ $\mathrm{cm}^{2}$, the electrode showed $23 \%$ higher power density at $0.6 \mathrm{~V}$ than that of a Pt/C (TKK, $45.9 \mathrm{wt} \%$ ) electrode with a catalyst loading of $0.41 \mathrm{mg}_{\mathrm{Pt}} / \mathrm{cm}^{2}$.

Compared with carbon materials, metal oxides like $\mathrm{TiO}_{2}$ [116] and $\mathrm{WO}_{3}$ [117], which are facile to construct nanoarray structures and exhibit better acid and corrosion resistance, have also been utilized as support. Zhang et al. [118] prepared ordered $\mathrm{TiO}_{2}$ nanotube arrays followed by hydrogen annealing to improve their electronic conductivity. PtPdSn ternary alloy catalysts were subsequently supported by precursor impregnation and hydrogen reduction at high temperatures to prepare the CL. To modulate the conductivity of $\mathrm{TiO}_{2}$ support, Chen et al. [119] developed $\mathrm{Pt}_{-} \mathrm{TiO}_{2} @ \mathrm{PANI}$ core-shell nanowire arrays insitu grown on GDLs. With a cathode catalyst loading of $0.2 \mathrm{mg} / \mathrm{cm}^{2}$, the Pt-TiO $@$ PANI electrode showed a peak power density that is $0.77 \mathrm{~W} / \mathrm{cm}^{2}$ higher than $0.70 \mathrm{~W} / \mathrm{cm}^{2}$ of a commercial Pt/C electrode (JM, $40 \mathrm{wt} \%$ ). To further improve the $\mathrm{TiO}_{2}$ conductivity, Jiang et al. [120] prepared $\mathrm{TiO}_{2}$ nanorod arrays on carbon paper with a seed-assisted hydrothermal method and converted it into $\mathrm{TiO}_{2}-\mathrm{C} \mathrm{NR}$ arrays by heat treatment at $900{ }^{\circ} \mathrm{C}$ under methane atmosphere. Pt nanoparticles are subsequently deposited by

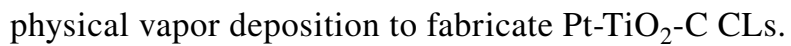

\subsubsection{Ordered Catalyst Structures}

Apart from the construction of the ordered support structure, arrays of 1D catalyst nanostructures, i.e., Pt and Pt alloy nanowires and nanotubes, are also introduced to fabricate 3D-ordered CLs.

By a facile in-situ growing approach using a formic acidreducing method, Du et al. [121, 122] developed gas diffusion electrodes (GDEs) with Pt nanowires arrays in-situ grown on GDLs. The simple one-step fabrication procedure was achieved in an aqueous solution at room temperature, without using any template or organic solvent. However, the hydrophobic GDL surface limits its surface wettable ability with the aqueous reaction solution, resulting in the formation of large Pt nanowire agglomerates. To improve the 


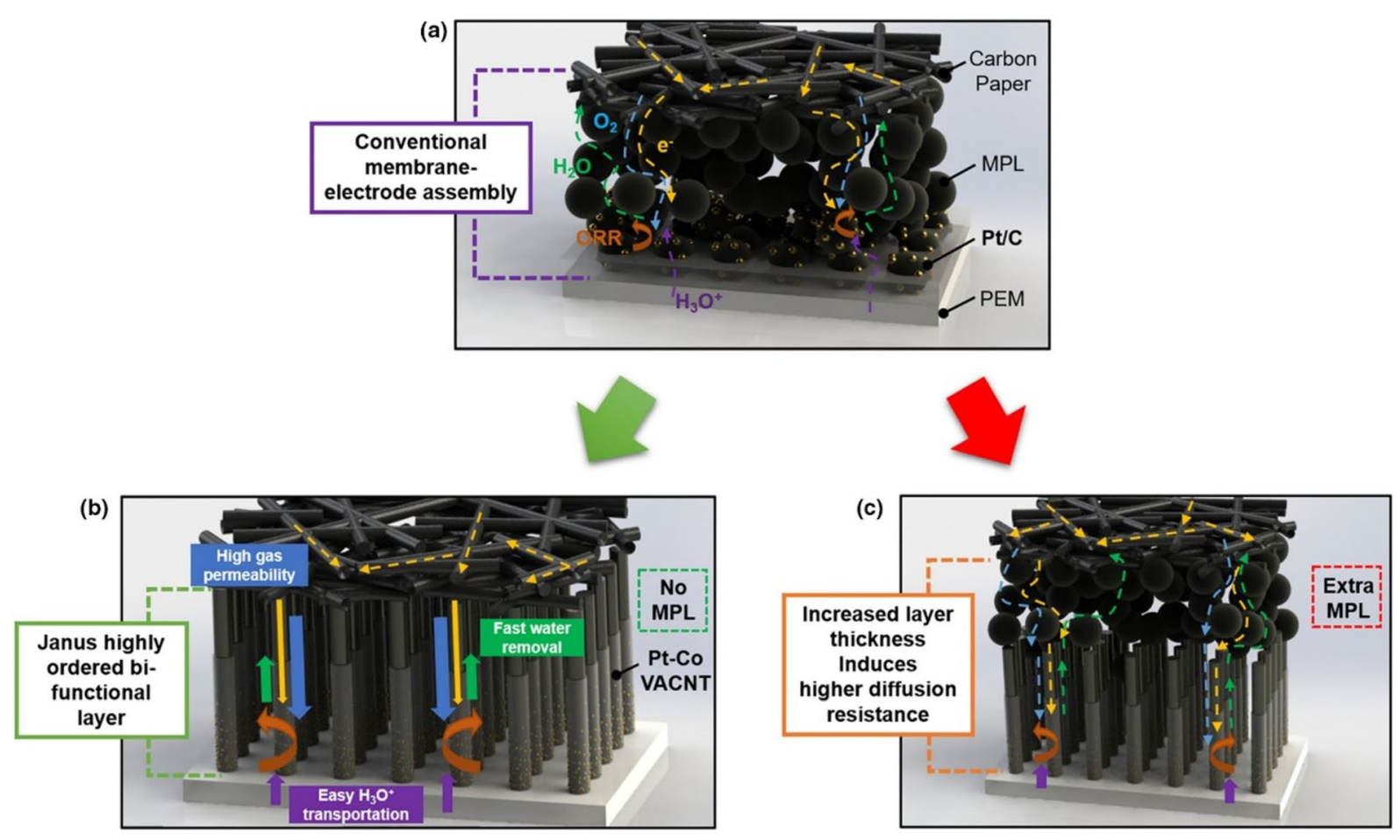

Fig. 10 The schematic illustration of a the conventional MEA structure, $\mathbf{b}$ the Janus highly ordered bi-functional layer with super gas-water diffusion capability, and $\mathbf{c}$ problems related to the additional MPL layer for ordered-structured MEA [16]

distribution of Pt nanowires to reduce the mass transport resistance and enhance the catalyst utilization, Pd nanoseeds [123], high growing temperature [124] and plasma nitriding treatment [125] have been explored to create more nucleation sites on the GDL surface to induce the Pt nanowire growth. Thin CLs with a monolayer array of ultrathin $\mathrm{Pt}$ nanowires with a diameter of ca. $3 \mathrm{~nm}$ were achieved, and better power performance was demonstrated compared to the latest commercial TKK Pt/C catalysts. As an advancement of this approach, Sui et al. grew Pt nanowire arrays on PEM $[126,127]$ and decal [128] substrate (e.g., PTFE sheet) by introducing a carbon matrix layer for enabling nucleation sites to overcome the inert surface challenge. By introducing a very small amount of $\mathrm{Pt} / \mathrm{C}\left(0.005 \mathrm{mg}_{\mathrm{Pl}} / \mathrm{cm}^{2}\right)$ into the carbon matrix [129], the nanowire distribution was further improved. With a total cathode Pt loading of $0.205 \mathrm{mg}_{\mathrm{Pt}} /$ $\mathrm{cm}^{2}$, the Pt nanowire electrode showed a comparable power density as the GDE made from commercial Pt/C catalysts (JM, $40 \mathrm{wt} \%$ ) with a loading of $0.4 \mathrm{mg}_{\mathrm{Pt}} / \mathrm{cm}^{2}$. However, because of the large bulk volume of the anisotropic $\mathrm{Pt}$ nanowires, their ECSA are usually much lower compared to $\mathrm{Pt} / \mathrm{C}$ nanoparticle catalysts. The development of electrodes from single-crystal 1D Pt-based alloy catalyst arrays [130, 131 ]can be a potential solution to address this issue. However, their facile preparation for practical application is still highly challenging at the moment.
Another potential strategy is to use porous 1D nanostructures, e.g., Pt or Pt alloy nanotubes. Besides the conventional anodized aluminium oxide (AAO) template method [132], $\mathrm{ZnO}$ nanorod arrays in-situ grown on GDL surface by a hydrothermal method were also explored as the sacrificial template [65]. Pt was deposited by physical vapor deposition (PVD), and the template was removed to obtain Pt nanotube array electrodes. Electrodes from PtCo bimetallic nanotube arrays were also demonstrated by using templated $\mathrm{Co}-\mathrm{OH}-\mathrm{CO}_{3}$ nanowire arrays (NWAs) with surface Pt coating using the magnetron sputtering technique [133]. However, due to the large size of the prepared catalyst nanotubes (diameter of 90-100 nm and wall thickness of 8-17 nm) and the limit in achieving a high catalyst loading by the PVD technique, the nanotube array electrodes both showed lower power densities than that from commercial Pt/C catalysts in the fuel cell test.

\section{High-Power-Density Operation}

\subsection{Mass Transport at Large Current Density Operation}

Enhancement of fuel cell performance at large current densities is essential to achieve high-power-density operation and reduce system cost in automotive applications. The concentration polarization is the major barrier to achieving high performance at a large current density operation. It is caused 
by the mass transport resistance of reactants $\left(\mathrm{O}_{2}, \mathrm{H}_{2}\right)$ and product (water) taking place near active catalytic sites [134]. Besides, the transport of liquid water in the CL also affects the membrane and electrode humidification states, as well as the internal resistance and catalyst efficiency that determine fuel cell performance [135]. A large operating current density may result in oxygen starvation at the catalyst surface because of the high water formation rate at the cathode. Thereby, appropriate water/heat management is essential for proton conducting and reactant transport, mitigating severe performance loss in operation [136].

There are two major strategies applied to achieve highpower performance at large-current-density operation: optimization engineering of the electrode structure and MEA configuration, and minimizing mass transfer resistance by providing the best operating conditions for electrochemical reactions in the optimal CL [8]. Ramaswamy and Kumaraguru [137] proposed that the material and design selection in the $\mathrm{CL}$ affected the local- $\mathrm{O}_{2}$ and bulk- $\mathrm{H}^{+}$transport thus improving large current density performance in PEMFCs. An MEA with uniform size distribution and homogeneous local dispersion of Pt nanoparticle catalysts showed a superb performance with a potential enhancement of $29 \mathrm{mV}$ at 1.6 $\mathrm{A} / \mathrm{cm}^{2}$ [138]. Lee et al. [139] investigated increasing the average pore size from 50 to $60 \mathrm{~nm}$ in the CL by introducing PEG addition to catalyst ink to achieve reduced mass transport resistance in operation. Besides the above-mentioned innovation of material and electrode structure, other efforts reported related to mass transfer inside the MEAs were focused on water/heat management, flow field design and the humidification strategy at the fuel cell stack level for a full play of the MEA potential [8].

\subsection{Development and Application Status of PEMFCs for Vehicles}

FCVs have advanced rapidly in recent years as the automotive OEMs have released commercially available FCV models. According to Global EV Outlook 2020 from International Energy Agency (IEA), total sales of FCVs in 2019 were 12,350 , adding the global stock to 25,210 units. Passenger cars account for the majority of FCV sales and stocks. Toyota (Mirai), Hyundai (Nexo) and Honda (Clarity Fuel Cell) are the main players of the current FCV market. Toyota has also unveiled its second-generation Mirai concept in 2019 [140]. Additionally, expert assessments of the cost and expected future performance of PEMFCs for FCVs were reported under the DOE support [141]. Thirty-nine experts, spreading across academia, government and industry, were interviewed to assess system cost, stack durability and power density. Most experts identified high PGM loading as the most significant barrier. Improving stack to operate at a high-power density is considered as the most potential strategy to reduce the amount of expensive materials and, therefore, stack cost.

PEMFCs used in the second-generation Mirai represent the state-of-the-art development in this area. To reach highpower performance at large current density operation, an innovative cell flow field plate is adopted to improve gas diffusion and lower concentration overvoltage, and new electrode structures are developed to increase proton conductivity for a lower resistance overpotential and boost catalytic activity for lower activation loss. As a result, the maximum sweep current per unit area of the electrode improved substantially, increasing the current density by a factor of 2.4 compared to the PEMFC in the first-generation Mirai launched in 2014 [142]. Figure 11 shows the fuel cell polarization curve of the first-generation TOYOTA Mirai. This graph was generated under the condition of NEDCx2, UDDS $x 3$, Highwayx 2 , US06 $\times 2$, maximum acceleration $\times 3$ and steady-state speed tests [143]. All of the collected data are shown in the red dots, including a set of the stack mapping data and the mapping minimum cell data. The fuel cell stack consists of 370 cells and each cell has an active area of $237 \mathrm{~cm}^{2}$. It delivers a peak power of $114 \mathrm{~kW}$ with a volume power density of $3.1 \mathrm{KW} / \mathrm{L}$ and a weight power density of $2.0 \mathrm{~kW} / \mathrm{kg}^{1}$. Very recently the early released data reports that these parameters have been improved to $128 \mathrm{~kW}, 4.4 \mathrm{~kW} / \mathrm{L}$ and $4 \mathrm{~kW} / \mathrm{g}$, respectively, for the second-generation Mirai.

More recently, in a commercialization-focused project under the EU FCH2-RIA Funding Scheme of "Volume Manufacturing of PEM FC Stacks for Transportation and Inline Quality Assurance (VOLUMETRIQ)," a full-size stack developed with 299 cells provided a total power of $111 \mathrm{~kW}$. Figure 12 shows the stack polarization plot under the ElringKlinger AG (EK, DE) optimized conditions, delivering $2.5 \mathrm{~A} / \mathrm{cm}^{2}$ at $0.6 \mathrm{~V}$. By associated improvements in the ionomer used for the membrane, cathode catalyst construction, compression set, GDLs and cell hardware, VOLUMETRIQ has achieved a leading single-cell power density of $2.67 \mathrm{~A} /$ $\mathrm{cm}^{2}$ at $0.6 \mathrm{~V}\left(1.6 \mathrm{~W} / \mathrm{cm}^{2}\right)$ with catalyst-coated membranes

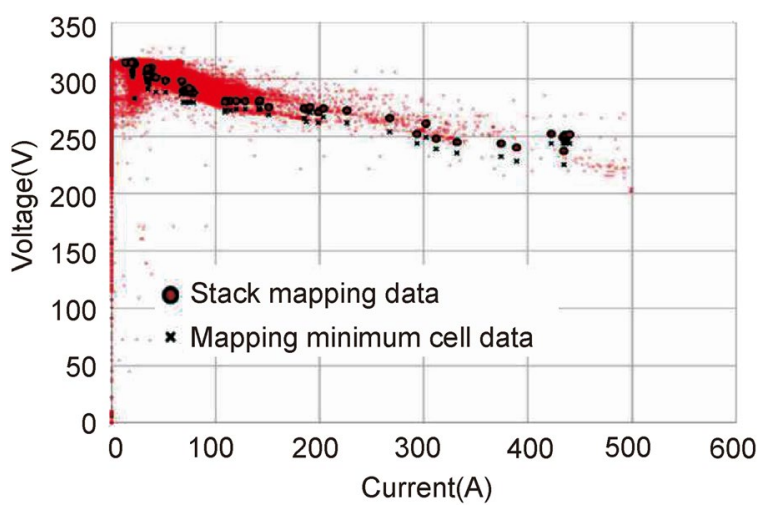

Fig. 11 Toyota Mirai fuel cell polarization curve [143] 
(CCMs) produced at volume. Based on the full stack result, the calculated volumetric power density reached $5.4 \mathrm{~kW} / \mathrm{L}$ including endplates and $6.6 \mathrm{~kW} / \mathrm{L}$ on the cell block, which is above the state-of-the-art fuel cell technology [144].

A high-performance proton exchange membrane (PEM) fuel cell stack in an industry-leading volumetric high-power density of $4.3 \mathrm{~kW} / \mathrm{L}$ excluding plate hardware, with highpower output up to $130-\mathrm{kW}$ rated power and $140-\mathrm{kW}$ maximum power, was launched by Ballard Power Systems in Sep. 2020.

Many governments have formulated roadmaps for FCVs. The DoE objectives are to develop a $65 \%$ peak-efficiency and direct hydrogen fuel cell power system for transportation that can achieve 5000-h durability (ultimate $8000 \mathrm{~h}$ ) and be mass-produced at $40 \mathrm{USD} / \mathrm{kW}$ by 2020 (ultimate $30 \mathrm{USD} /$ kW) [145]. The Fuel Cells and Hydrogen Joint Undertaking (FCH JU) published FUTURE TARGETS of Fuel Cell and Hydrogen-Transport Applications as derived from the Multi Annual Work Plan, as shown in Table 1 [146].

While much progress has been made and the current parameters are much closer to meeting the DOE 2020 targets, FCV manufacturers will need to make improvements to achieve the goal of 65\% peak efficiency [147]. The Ministry of Economy, Trade and Industry (METI) in Japan announced the revised New Strategic Roadmap for Hydrogen and Fuel Cells in September 2019. The target of the volumetric power density of PEMFC stacks for transportation will achieve $6.0 \mathrm{~kW} / \mathrm{L}$ with a PGM loading of $0.1 \mathrm{~g} / \mathrm{kW}$ by 2030 [148].

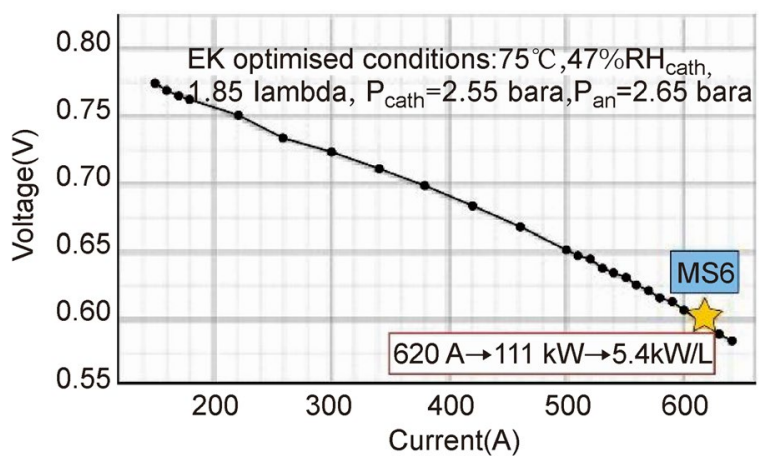

Fig. 12 Stack IV plot under the "VOLUMETRIQ" of FCH2-RIA Funding Scheme [144]
In Europe, FCH JU, a unique public-private partnership, continues supporting research, technological development and demonstration activities in fuel cell and hydrogen energy technologies. In a recent FCH2-RIA call (FCH-01-2-2020) of "Durability-Lifetime of Stacks for Heavy-Duty Trucks" expected for 3-year duration, the main targeted KPIs are to achieve (i) power density $>1.2 \mathrm{~W} / \mathrm{cm}^{2}$ at $0.675 \mathrm{~V} /$ cell; (ii) PGM loading $<0.3 \mathrm{~g} / \mathrm{kW}$; and (iii) system durability: 30,000 projected hours with less than $10 \%$ performance loss at nominal power.

Further improvement of the fuel cell stack, especially on a significant reduction of the cathode Pt loading to below $0.1 \mathrm{mg}_{\mathrm{P}} / \mathrm{cm}^{2}$, should be achieved for PEMFCs to operate at a large current density, i.e., at a high-power density, in order to keep the overall stack size and cost small in large-scale commercialization of FCVs.

\section{Perspectives and Summary}

The above discussions of the catalyst and ionomer development, ionomer/catalyst interface, pore feature controlling and 3D-ordered catalyst layers provide a basis for understanding the function of interface, structure and transport phenomena in the catalyst layer and aid the rational design of cathodes for high-power-density operation. As a functional cathode, the essential factors to deliver high-power performance in practical operation include well-connected network of catalysts and support for electrons to move to active catalytic sites, well-linked ionomer paths for effectively transferring protons and interconnected pores through the catalyst layer to bring oxygen to the triple-phase boundary and take generated water out. The conventional $\mathrm{Pt} / \mathrm{C}$ cathodes, after the nearly half-century development, can provide a power density up to $1.39 \mathrm{~W} / \mathrm{cm}^{2}$ and are still commonly used in commercial PEMFCs. However, they are still limited to the relatively low-power performance and durability in fuel cell operation, and high oxygen transport losses because of the randomly distributed catalysts and pores, which are still great technical hurdles in developing PEMFCs for highpower-density operation.

In the context of developing highly active catalysts, the investigations were mainly focused on Pt-based alloy catalysts to improve catalytic activities, and core-shell and
Table 1 Fuel cell system specifications by FCH JU FUTURE TARGETS [147]

\begin{tabular}{lllll}
\hline Parameter & Unit & Target 2020 & Target 2024 & Target 2030 \\
\hline Fuel cell system durability & $\mathrm{h}$ & 5000 & 6000 & 7000 \\
Fuel cell system cost & EUR/kW & 60 & 50 & 40 \\
Areal power density & $\mathrm{W} / \mathrm{cm}^{2}$ & 1.5 & 1.8 & 2.0 \\
PGM loading & $\mathrm{G} / \mathrm{kW}$ & 0.17 & 0.08 & 0.05 \\
Cell volumetric power & $\mathrm{kW} / \mathrm{L}$ & 7.3 & 9.3 & 10.0 \\
\hline
\end{tabular}


alternative PGM-free catalysts to reduce the catalyst cost. So far, Pt-based catalysts still outperform other catalysts over an entire range of properties. PtNi and PtCo catalysts have been demonstrated as the most promising catalysts, and the PtCo catalyst is also the one deployed in Toyota Mirai FCVs. While most exciting catalytic properties have been reported from advanced shape-controlled catalysts from $\mathrm{PtNi}$ alloys, e.g., nanoframes, nanopellets and nanowires, most of them were only demonstrated by half-cell electrochemical measurement using the RDE technique in liquid electrolytes and don't work in practical electrodes in single fuel cells. In recent years, the established floating electrode technique and the half-cell gas diffusion electrode technique enable the testing of advanced electrocatalysts at a relatively high catalyst loading and large current density under more realistic operation conditions. These stepwise approaches can potentially bridge the catalytic performance evaluation between the RDE and MEA approaches, shedding light on the engineering of advanced catalysts and bringing them to PEMFC applications, in particular the ultrafine jagged $\mathrm{Pt}$ nanowire that shows an ECSA of $118 \mathrm{~m}^{2} / \mathrm{g}_{\mathrm{Pt}}$ and the highest mass activity $\left(13.6 \mathrm{~A} / \mathrm{g}_{\mathrm{Pt}}\right)$ reported so far [40]. Electrochemical engineering research for a full projection of the outstanding catalytic performance of these advanced catalysts in real electrodes could have a significant contribution to the PEMFC development.

For PEMFCs with an ultralow Pt loading catalyst operating at a high-power density, the contribution of oxygen transfer characteristics will differ from those in common medium catalyst loading devices. Thereby, quantification and separation of various oxygen transport resistance including molecular diffusion, Knudsen diffusion and oxygen penetrating through the ionomer layer on catalyst surface will be highly beneficial to understand the bottleneck limits for improving power performance of cathodes and pinpointing the investigation to effectively address the challenge. For example, St-Pierre. et. al [102] developed the curve fitting method to be applied in the power densities recorded from the single-cell test under different oxygen concentrations in various inert gases (e.g., $\mathrm{N}_{2}, \mathrm{CO}_{2}$, $\mathrm{He}$ ), taking the advantages of the relationship between molecular diffusion and diluted molecular mass, as well as the independence of Knudsen diffusion with the oxygen concentration. While this complex method can give a useful estimation for various parts of the oxygen diffusion, a further advancement to provide accurate data with a simple approach could be more valuable for the practical test.

For PEMFCs with an ultralow catalyst loading, the ionomer permeability resistance (for oxygen penetration) will become a major contribution to the oxygen transport resistance. In this case, precisely controlled distribution of ionomer on catalyst surface is of great importance to create optimized interfacial structure and phenomena. This is determined by the properties of both ionomer itself and catalyst support surface. Regarding the ionomer, PFSA types are currently the best choice for developing large-currentdensity operation cathodes. The development of SSC PFSA ionomers has been demonstrated as a success to improve the proton conductivity and gain better distribution on the catalyst surface to create a high micropore volume in the catalyst layer. But for isolated catalyst agglomerates coated with an SSC ionomer, a combination with LSC ionomers (e.g., Nafion) can help bridge vacancies to form highly connected ionomer networks in the catalyst layer. Another choice is to use hydrophobic protic ionic liquids together with the LSC ionomers, taking advantage of their easily penetrating into the pores, excellent proton conductivity, good oxygen solubility and diffusivity and high water-repelling nature. But, to really make this approach work, their stability needs to be dramatically improved for severe fuel cell operating conditions. The research of polymerization with well-controlled structure could be a potential solution to this issue. Concerning surface modification of the catalyst support to achieve uniform distribution of ionomers, breakthroughs have been achieved through the carbon support functionalization with $\mathrm{NH}_{\mathrm{x}}$ or nitrogen groups, which also demonstrated the significant importance of ionomer distribution to improve oxygen mass transport characteristics within the catalyst layer. The design of the carbon support with controlled open pore size excess can also be a large contribution to improve fuel cell performance. To achieve this, a careful balance is necessary between trapping catalyst nanoparticles within pores to avoid poisoning by direct contact with ionomers and as close as to the surface to be accessible for oxygen and proton transfer. The use of SSC ionomers and ILs can play a big role here. Fundamental research of the adhesion force between the ionomers and catalyst surface can be an effective tool to monitor their interaction to help the surface optimization of catalyst or catalyst support, in particular in searching for a useful approach to distributing ionomer on the highly active shape-controlled catalysts that possess complete different surface properties to the carbon support, e.g., for building effective TPB within the electrodes from nanowires to fully transfer their high catalytic activities to fuel cells.

Given that the 3D-ordered catalyst layer is effective for facilitating molecular and Knudsen diffusion based on their open porous structure and thin catalyst layer [149], the adoption of highly active catalysts can be a promising strategy to realize high-power-density operation. However, the current approach by depositing catalyst nanoparticles using physical techniques on 1D support arrays is limited to the low catalyst loading and ECSA. Although a very high specific power density can be obtained, the fuel cell power density is still lower compared to the conventional $\mathrm{Pt} / \mathrm{C}$ electrode with a medium catalyst loading. If 3D-ordered electrodes can be built from ultrafine jagged Pt nanowire arrays, their large 
ECSA and high mass activity can address these challenges, thus enabling PEMFCs for high-power-density operation.

In summary, the progress of catalysts, ionomers, electrode structure together with advanced stack design have reached a volume power density of $4.4 \mathrm{~kW} / \mathrm{L}$ for PEMFCs in the second-generation Toyota Mirai FCVs. Next-generation PEMFCs, if intended to achieve $6 \mathrm{~kW} / \mathrm{L}$, should possess oxygen mass transport properties that using an ultralow loading of highly active Pt-based catalysts, uniform distribution of ionomer on the catalyst surface with minimized ionomer permeability resistance and catalyst poisoning, 3D-ordered catalyst layers with significantly reduced oxygen molecular and Knudsen diffusion resistance. This will require multi-disciplinary research joining electrochemical engineering study to provide fundamental knowledge and understanding of the adhesion of ionomers on the catalyst and support surface, agglomeration phenomena of catalysts and ionomers, quantification and separation of oxygen transport resistance, and oxygen and water permeability through the thin ionomer layer on the catalyst surface.

Acknowledgement SD would like to acknowledge support from the Engineering and Physical Sciences Research Council (EPSRC, EP/ L015749/1). SS gratefully acknowledges the financial supports from the National Natural Science Foundation of China under grant agreement No 21576164. Thanks are also to the support from Guangdong Academy of Sciences project (2019 GDASYL-0503005).

\section{Declarations}

Conflict of interest On behalf of all the authors, the corresponding author states that there is no conflict of interest.

Open Access This article is licensed under a Creative Commons Attribution 4.0 International License, which permits use, sharing, adaptation, distribution and reproduction in any medium or format, as long as you give appropriate credit to the original author(s) and the source, provide a link to the Creative Commons licence, and indicate if changes were made. The images or other third party material in this article are included in the article's Creative Commons licence, unless indicated otherwise in a credit line to the material. If material is not included in the article's Creative Commons licence and your intended use is not permitted by statutory regulation or exceeds the permitted use, you will need to obtain permission directly from the copyright holder. To view a copy of this licence, visit http://creativecommons.org/licenses/by/4.0/.

\section{References}

1. Perng, S., Wu, H.: Effect of the prominent catalyst layer surface on reactant gas transport and cell performance at the cathodic side of a PEMFC. Appl. Energy 87(4), 1386-1399 (2010). https://doi.org/10.1016/j.apenergy.2009.08.006

2. Vignarooban, K., Lin, J., Arvay, A., Kolli, S., Kruusenberg, I., Tammeveski, K., Munukutla, L., Kannan, A.M.: Nano-electrocatalyst materials for low temperature fuel cells: a review. Chin. J. Catal. 36(4), 458-472 (2015). https://doi.org/10.1016/ s1872-2067(14)60175-3
3. Wang, Y., Long, W., Wang, L., Yuan, R., Ignaszak, A., Fang, B., Wilkinson, D.P.: Unlocking the door to highly active ORR catalysts for PEMFC applications: polyhedron-engineered Pt-based nanocrystals. Energy Environ. Sci. 11(2), 258-275 (2018). https://doi.org/10.1039/C7EE02444D

4. Cindrella, L., Kannan, A.M., Lin, J.F., Saminathan, K., Ho, Y., Lin, C.W., Wertz, J.: Gas diffusion layer for proton exchange membrane fuel cells-a review. J. Power Sour. 194(1), 146160 (2009). https://doi.org/10.1016/j.jpowsour.2009.04.005

5. Kongkanand, A., Mathias, M.F.: The priority and challenge of high-power performance of low-platinum proton-exchange membrane fuel cells. J. Phys. Chem. Lett. 7(7), 1127-1137 (2016). https://doi.org/10.1021/acs.jpclett.6b00216

6. Ferreira-Aparicio, P., Chaparro, A.M., Antonia, F.M., Conde, J.J., Brightman, E., Hinds, G.: Degradation study by start-up/ shut-down cycling of superhydrophobic electrosprayed catalyst layers using a localized reference electrode rechnique. ACS Appl. Mater. Interfaces 9(12), 10626-10636 (2017). https:// doi.org/10.1021/acsami.6b15581

7. Ohyagi, S., Sasaki, T.: Durability of a PEMFC Pt-Co cathode catalyst layer during voltage cycling tests under supersaturated humidity conditions. Electrochim. Acta 102, 336-341 (2013). https://doi.org/10.1016/j.electacta.2013.04.060

8. Deng, X., Zhang, J., Fan, Z., Tan, W., Yang, G., Wang, W., Zhou, W., Shao, Z.: Understanding and engineering of multiphase transport processes in membrane electrode assembly of proton-exchange membrane fuel cells with a focus on the cathode catalyst layer: a review. Energy Fuels 34(8), 9175-9188 (2020). https://doi.org/10.1021/acs.energyfuels.0c02101

9. Escribano, S., Aldebert, P., Pineri, M.: Volumic electrodes of fuel cells with polymer electrolyte membranes: electrochemical performances and structural analysis by thermoporometry. Electrochim. Acta 43(14), 2195-2202 (1998). https://doi.org/ 10.1016/S0013-4686(97)10108-6

10. Prasanna, M., Cho, E.A., Lim, T.H., Oh, I.H.: Effects of MEA fabrication method on durability of polymer electrolyte membrane fuel cells. Electrochim. Acta 53(16), 5434-5441 (2008). https://doi.org/10.1016/j.electacta.2008.02.068

11. Chong, L., Wen, J., Kubal, J., Sen, F.G., Zou, J., Greeley, J., Chan, M., Barkholtz, H., Ding, W., Liu, D.: Ultralow-loading platinum-cobalt fuel cell catalysts derived from imidazolate frameworks. Science 362(6420), 1276-1281 (2018). https:// doi.org/10.1126/science.aau0630

12. Ott, S., Orfanidi, A., Schmies, H., Anke, B., Nong, H.N., Hübner, J., Gernert, U., Gliech, M., Lerch, M., Strasser, P.: Lonomer distribution control in porous carbon-supported catalyst layers for high-power and low Pt-loaded proton exchange membrane fuel cells. Nat. Mater. 19(1), 77-85 (2020). https:// doi.org/10.1038/s41563-019-0487-0

13. Ma, Z., Cano, Z.P., Yu, A., Chen, Z., Jiang, G., Fu, X., Yang, L., Wu, T., Bai, Z., Lu, J.: Enhancing oxygen reduction activity of Pt-based electrocatalysts: from theoretical mechanisms to practical methods. Angewandte Chemie-International Edition 59(42), 18334-18348 (2020). https://doi.org/10.1002/anie. 202003654

14. Pan, M., Li, C., Liao, J., Lei, H., Pan, C., Meng, X., Huang, H.: Design and modeling of PEM fuel cell based on different flow fields. Energy 207, 118331 (2020). https://doi.org/10.1016/j. energy.2020.118331

15. Weng, L., Jhuang, J., Bhavanari, M., Lee, K., Lai, Y., Tseng, C.: Effects of assembling method and force on the performance of proton-exchange membrane fuel cells with metal foam flow field. Int. J. Energy Res. 44(12), 9707-9713 (2020). https://doi.org/10. 1002/er.5611

16. Meng, X., Deng, X., Zhou, L., Hu, B., Tan, W., Zhou, W., Liu, M., Shao, Z.: A highly ordered hydrophilic-hydrophobic janus 
Bi-functional layer with ultralow Pt loading and fast gas/water transport for fuel cells. Energy Environ. Mater. (2020). https:// doi.org/10.1002/eem2.12105

17. Chen, T., Liu, S., Zhang, J., Tang, M.: Study on the characteristics of GDL with different PTFE content and its effect on the performance of PEMFC. Int. J. Heat Mass Transf. 128, 1168-1174 (2019). https://doi.org/10.1016/j.ijheatmasstrans fer.2018.09.097

18. Mennola, T., Mikkola, M., Noponen, M., Hottinen, T., Lund, P.: Measurement of ohmic voltage losses in individual cells of a PEMFC stack. J. Power Sour. 112(1), 261-272 (2002). https:// doi.org/10.1016/S0378-7753(02)00391-9

19. Chen, W., Chen, S.: Effect of ink solvents on low-Pt loading proton exchange membrane fuel cell performance. Acta Phys. Chim. Sin. 35(5), 517-522 (2019). https://doi.org/10.3866/pku. whxb201806011

20. Long, Z., Gao, L., Li, Y., Kang, B., Lee, J.Y., Ge, J., Liu, C., Ma, S., Jin, Z., Ai, H.: Micro galvanic cell to generate PtO and extend the triple-phase boundary during self-assembly of Pt/C and nafion for catalyst layers of PEMFC. ACS Appl. Mater. Interfaces. 9(44), 38165-38169 (2017). https://doi.org/10.1021/ acsami.7b11852

21. O'Hayre, R., Barnett, D.M., Prinz, F.B.: The triple phase boundary - a mathematical model and experimental investigations for fuel cells. J. Electrochem. Soc. 152(2), A439-A444 (2005). https://doi.org/10.1149/1.1851054

22. Meyer, Q., Mansor, N., Iacoviello, F., Cullen, P.L., Jervis, R., Finegan, D., Tan, C., Bailey, J., Shearing, P.R., Brett, D.: Investigation of hot pressed polymer electrolyte fuel cell assemblies via X-ray computed tomography. Electrochim. Acta 242, 125-136 (2017). https://doi.org/10.1016/j.electacta.2017.05.028

23. You, L.X., Liu, H.T.: A parametric study of the cathode catalyst layer of PEM fuel cells using a pseudo-homogeneous model. Int. J. Hydrogen Energy 26(9), 991-999 (2001). https://doi.org/10. 1016/s0360-3199(01)00035-0

24. Lange, K.J., Sui, P.C., Djilali, N.: Pore scale simulation of transport and electrochemical reactions in reconstructed PEMFC catalyst layers. J. Electrochem. Soc. 157(10), B1434-B1442 (2010). https://doi.org/10.1149/1.3478207

25. Lange, K.J., Sui, P.C., Djilali, N.: Determination of effective transport properties in a PEMFC catalyst layer using different reconstruction algorithms. J. Power Sour. 208, 354-365 (2012). https://doi.org/10.1016/j.jpowsour.2011.11.001

26. Siddique, N.A., Liu, F.: Process based reconstruction and simulation of a three-dimensional fuel cell catalyst layer. Electrochim. Acta 55(19), 5357-5366 (2010). https://doi.org/10.1016/j.elect acta.2010.04.059

27. Karuppanan, K.K., Raghu, A.V., Panthalingal, M.K., Pullithadathil, B.: Tailored hollow core/mesoporous shell carbon nanofibers as highly efficient and durable cathode catalyst supports for polymer electrolyte fuel cells. ChemElectroChem 6(7), 2029-2042 (2019). https://doi.org/10.1002/celc.201900065

28. Martin, S., Li, Q., Jensen, J.O.: Lowering the platinum loading of high temperature polymer electrolyte membrane fuel cells with acid doped polybenzimidazole membranes. J. Power Sour. 293, 51-56 (2015). https://doi.org/10.1016/j.jpowsour.2015.05.031

29. Borup, R.L., Kusoglu, A., Neyerlin, K.C., Mukundan, R., Ahluwalia, R.K., Cullen, D.A., More, K.L., Weber, A.Z., Myers, D.J.: Recent developments in catalyst -related PEM fuel cell durability. Curr. Opin. Electrochem. 21, 192-200 (2020). https://doi.org/10. 1016/j.coelec.2020.02.007

30. Sui, S., Wang, X., Zhou, X., Su, Y., Riffatc, S., Liu, C.: A comprehensive review of Pt electrocatalysts for the oxygen reduction reaction: nanostructure, activity, mechanism and carbon support in PEM fuel cells. J. Mater. Chem. A 5(5), 1808-1825 (2017). https://doi.org/10.1039/c6ta08580f
31. Carpenter, M.K., Moylan, T.E., Kukreja, R.S., Atwan, M.H., Tessema, M.M.: Solvothermal synthesis of platinum alloy nanoparticles for oxygen reduction electrocatalysis. J. Am. Chem. Soc. 134(20), 8535-8542 (2012). https://doi.org/10.1021/ja300756y

32. RF Service: Platinum in fuel cells gets a helping hand. Science 315 (5809):172(2007). doi:https://doi.org/10.1126/science.315. 5809.172

33. Jia, Y., Jiang, Y., Zhang, J., Zhang, L., Chen, Q., Xie, Z., Zheng, L.: Unique excavated rhombic dodecahedral PtCu3 alloy nanocrystals constructed with ultrathin nanosheets of high-energy 110 facets. J. Am. Chem. Soc. 136(10), 3748-3751 (2014). https://doi.org/10.1021/ja413209q

34. Nie, Y., Li, L., Wei, Z.: Recent advancements in Pt and Pt-free catalysts for oxygen reduction reaction. Chem. Soc. Rev. 44(8), 2168-2201 (2015). https://doi.org/10.1039/c4cs00484a

35. Peng, X., Zhao, S., Omasta, T.J., Roller, J.M., Mustain, W.E.: Activity and durability of Pt-Ni nanocage electocatalysts in proton exchange membrane fuel cells. Appl. Catal. B 203, 927-935 (2017). https://doi.org/10.1016/j.apcatb.2016.10.081

36. Stamenkovic, V.R., Mun, B.S., Arenz, M., Mayrhofer, K.J., Lucas, C.A., Wang, G., Ross, P.N., Markovic, N.M.: Trends in electrocatalysis on extended and nanoscale Pt-bimetallic alloy surfaces. Nat. Mater. 6(3), 241-247 (2007). https://doi.org/10. 1038/nmat 1840

37. Sasaki, K., Kuttiyiel, K.A., Adzic, R.R.: Designing high performance Pt monolayer core-shell electrocatalysts for fuel cells. Curr. Opin. Electrochem. 21, 368-375 (2020). https://doi.org/ 10.1016/j.coelec.2020.03.020

38. Stamenkovic, V.R., Fowler, B., Mun, B.S., Wang, G., Ross, P.N., Lucas, C.A., Marković, N.M.: Improved oxygen reduction activity on Pt3Ni(111) via increased surface site availability. Science 315(5811), 493-497 (2007). https://doi.org/10.1126/science. 1135941

39. Chen, C., Kang, Y., Huo, Z., Zhu, Z., Huang, W., Xin, H.L., Snyder, J.D., Li, D., Herron, J.A., Mavrikakis, M., Chi, M., More, K.L., Li, Y., Markovic, N.M., Somorjai, G.A., Yang, P., Stamenkovic, V.R.: Highly crystalline multimetallic nanoframes with three-dimensional electrocatalytic surfaces. Science 343(6177), 1339-1343 (2014). https://doi.org/10.1126/science.1249061

40. Li, M., Zhao, Z., Cheng, T., Fortunelli, A., Chen, C., Yu, R., Zhang, Q., Gu, L., Merinov, B.V., Lin, Z., Zhu, E., Yu, T., Jia, Q., Guo, J., Zhang, L., Goddard, W.A., Huang, Y., Duan, X.: Ultrafine jagged platinum nanowires enable ultrahigh mass activity for the oxygen reduction reaction. Science 354(6318), 1414-1419 (2016). https://doi.org/10.1126/science.aaf9050

41. Suzuki, T.: (Invited) Fuel cell stack technology of toyota. ECS Trans. 75(14), 423-434 (2016). https://doi.org/10.1149/07514. 0423ecst

42. Cui, Y., Wu, Y., Wang, Z., Yao, X., Wei, Y., Kang, Y., Du, H., Li, J., Gan, L.: Mitigating metal dissolution and redeposition of Pt-Co catalysts in PEM fuel cells: impacts of structural ordering and particle size. J. Electrochem. Soc. 167(6), 064520 (2020). https://doi.org/10.1149/1945-7111/ab8407

43. Papadias, D.D., Ahluwalia, R.K., Kariuki, N., Myers, D., More, K.L., Cullen, D.A., Sneed, B.T., Neyerlin, K.C., Mukundan, R., Borup, R.L.: Durability of Pt-Co alloy polymer electrolyte fuel cell cathode catalysts under accelerated stress tests. J. Electrochem. Soc. 165(6), F3166-F3177 (2018). https://doi.org/10. 1149/2.0171806jes

44. Yarlagadda, V., Carpenter, M.K., Moylan, T.E., Kukreja, R.S., Koestner, R., Gu, W., Thompson, L., Kongkanand, A.: Boosting fuel cell performance with accessible carbon mesopores. ACS Energy Lett. 3(3), 618-621 (2018). https://doi.org/10.1021/acsen ergylett.8b00186

45. Chung, Y., Chung, D., Jung, N., Park, H., Sung, Y., Yoo, S.: Effect of surface composition of Pt-Fe nanoparticles for oxygen 
reduction reactions. Int. J. Hydrogen Energy 39(27), 1475114759 (2014). https://doi.org/10.1016/j.ijhydene.2014.07.097

46. Cai, B., Hübner, R., Sasaki, K., Zhang, Y., Su, D., Ziegler, C., Vukmirovic, M.B., Rellinghaus, B., Adzic, R.R., Eychmüller, A.: Core-Shell structuring of pure metallic aerogels towards highly efficient platinum utilization for the oxygen reduction reaction. Angew. Chem. Int. Ed. 57(11), 2963-2966 (2018). https://doi. org/10.1002/anie.201710997

47. Sasaki, K., Naohara, H., Choi, Y., Cai, Y., Chen, W.F., Liu, P., Adzic, R.R.: Highly stable Pt monolayer on PdAu nanoparticle electrocatalysts for the oxygen reduction reaction. Nature Commun. 3(1), 1115 (2012). https://doi.org/10.1038/ncomms2124

48. Wang, G., Osmieri, L., Star, A.G., Pfeilsticker, J., Neyerlin, K.C.: Elucidating the role of ionomer in the performance of platinum group metal-free catalyst layer via in situ electrochemical diagnostics. J. Electrochem. Soc. 167(4), 044519 (2020). https://doi. org/10.1149/1945-7111/ab7aa1

49. Wang, L., Wan, X., Liu, S., Xu, L., Shui, J.: Fe-N-C catalysts for PEMFC: progress towards the commercial application under DOE reference. J. Energy Chem. 39, 77-87 (2019). https://doi. org/10.1016/j.jechem.2018.12.019

50. Bonnefont, A., Ruvinskiy, P., Rouhet, M., Orfanidi, A., Neophytides, S., Savinova, E.: Advanced catalytic layer architectures for polymer electrolyte membrane fuel cells. WIREs Energy Environ. 3(5), 505-521 (2014). https://doi.org/10.1002/wene.110

51. Nyokong, T., Zagal, J., Bedioui, F., Dodelet, J.: N4-Macrocyclic metal complexes, pp. 83-147. Springer, New York (2006)

52. Zelenay, P.: Non-precious metal fuel cell cathodes: catalyst development and electrode structure design. 2016 Annual Merit Review (2016)

53. Li, J., Brüller, S., Sabarirajan, D.C., Ranjbar-Sahraie, N., Sougrati, M.T., Cavaliere, S., Jones, D., Zenyuk, I.V., Zitolo, A., Jaouen, F.: Designing the 3D architecture of PGM-Free cathodes for $\mathrm{H}_{2}$ /air proton exchange membrane fuel cells. ACS Appl. Energy Mater. 2(10), 7211-7222 (2019). https://doi.org/10.1021/ acsaem.9b01181

54. Wu, H., Shi, L., Lei, J., Liu, D., Qu, D., Xie, Z., Du, X., Yang, P., Hu, X., Li, J., Tang, H.: Nitrogen and sulfur co-doped carbon with three-dimensional ordered macroporosity: an efficient metal-free oxygen reduction catalyst derived from ionic liquid. J. Power Sources 323, 90-96 (2016). https://doi.org/10.1016/j. jpowsour.2016.05.044

55. Wang, K., Chen, H., Zhang, X., Tong, Y., Song, S., Tsiakaras, P., Wang, Y.: Iron oxide@ graphitic carbon core-shell nanoparticles embedded in ordered mesoporous $\mathrm{N}$-doped carbon matrix as an efficient cathode catalyst for PEMFC. Appl. Catal. B 264, 118468 (2020). https://doi.org/10.1016/j.apcatb.2019.118468

56. Kosmala, T., Bibent, N., Sougrati, M.T., Dražić, G., Agnoli, S., Jaouen, F., Granozzi, G.: Stable, active, and methanol-tolerant PGM-free surfaces in an acidic medium: electron tunneling at play in Pt/FeNC hybrid catalysts for direct methanol fuel cell cathodes. ACS Catal. 10(14), 7475-7485 (2020). https://doi.org/ 10.1021/acscatal.0c01288

57. Yang, X., Zhang, G., Du, L., Zhang, J., Chiang, F.K., Wen, Y., Wang, X., Wu, Y., Chen, N., Sun, S.: PGM-Free Fe/N/C and ultralow loading $\mathrm{Pt} / \mathrm{C}$ hybrid cathode catalysts with enhanced stability and activity in PEM fuel cells. ACS Appl. Mater. Interfaces. 12(12), 13739-13749 (2020). https://doi.org/10.1021/ acsami.9b18085

58. Ballard to Offer World's First PEM Fuel Cell Product Using Non Precious Metal Catalyst. (2017). https://www.ballard.com/ about-ballard/newsroom/news-releases/2017/09/13/ballard-tooffer-world-s-first-pem-fuel-cell-product-using-non-preciousmetal-catalyst.

59. Banham, D., Choi, J.Y., Kishimoto, T., Ye, S.: Integrating PGMfree catalysts into catalyst layers and proton exchange membrane fuel cell devices. Adv. Mater. 31(31), 1804846 (2019). https:// doi.org/10.1002/adma.201804846

60. Kim, K.H., Lee, K.Y., Kim, H.J., Cho, E., Lee, S.Y., Lim, T.H., Yoon, S.P., Hwang, I.C., Jang, J.H.: The effects of Nafion ${ }^{\circledR}$ ionomer content in PEMFC MEAs prepared by a catalyst-coated membrane (CCM) spraying method. Int. J. Hydrogen Energy 35(5), 2119-2126 (2010). https://doi.org/10.1016/j.ijhydene. 2009.11.058

61. Kusoglu, A., Weber, A.Z.: New insights into perfluorinated sulfonic-acid ionomers. Chem. Rev. 117(3), 987-1104 (2017). https://doi.org/10.1021/acs.chemrev.6b00159

62. Barbosa, R., Escobar, B., Cano, U., Ortegon, J., Sanchez, V.M.: Multiscale relationship of electronic and ionic conduction efficiency in a PEMFC catalyst layer. Int. J. Hydrogen Energy 41(42), 19399-19407 (2016). https://doi.org/10.1016/j.ijhydene. 2016.04.071

63. Woo, S., Lee, S., Taning, A.Z., Yang, T.H., Park, S.H., Yim, S.D.: Current understanding of catalyst/ionomer interfacial structure and phenomena affecting the oxygen reduction reaction in cathode catalyst layers of proton exchange membrane fuel cells. Curr. Opin. Electrochem. 21, 289-296 (2020). https://doi.org/10. 1016/j.coelec.2020.03.006

64. Garsany, Y., Atkinson, R.W., Sassin, M.B., Hjelm, R.M., Gould, B.D., Swider-Lyons, K.E.: Improving PEMFC performance using short-side-chain low-equivalent-weight PFSA lonomer in the cathode catalyst layer. J. Electrochem. Soc. 165(5), F381F391 (2018). https://doi.org/10.1149/2.1361805jes

65. Deng, R., Xia, Z., Sun, R., Wang, S., Sun, G.: Nanostructured ultrathin catalyst layer with ordered platinum nanotube arrays for polymer electrolyte membrane fuel cells. J. Energy Chem. 43, 33-39 (2020). https://doi.org/10.1016/j.jechem.2019.07.015

66. Ebenezer, D., Haridoss, P.: Effect of crosslinked poly(vinyl alcohol)/sulfosuccinic acid ionomer loading on PEMFC electrode performance. Int. J. Hydrogen Energy 42(7), 4302-4310 (2017). https://doi.org/10.1016/j.ijhydene.2017.01.124

67. Yang, Z., Li, J., Ling, Y., Zhang, Q., Yu, X., Cai, W.: Bottom-up design of high-performance Pt electrocatalysts supported on carbon nanotubes with homogeneous lonomer distribution. ChemCatChem 9(17), 3307-3313 (2017). https://doi.org/10.1002/cctc. 201700587

68. Dru, D., Baranton, S., Bigarré, J., Buvat, P., Coutanceau, C.: Fluorine-free Pt nanocomposites for three-phase interfaces in fuel cell electrodes. ACS Catal. 6(10), 6993-7001 (2016). https:// doi.org/10.1021/acscatal.6b02145

69. Li, Y., Van, C.T., Sun, R., Gawas, R., Wang, G., Tang, M., Elabd, Y.A., Snyder, J., Neyerlin, K.C.: Modifying the electrocatalystionomer interface via sulfonated poly(ionic liquid) block copolymers to enable high-performance polymer electrolyte fuel cells. ACS Energy Lett. 5(6), 1726-1731 (2020). https://doi.org/10. 1021/acsenergylett.0c00532

70. Snyder, J., Livi, K., Erlebacher, J.: Oxygen reduction reaction performance of [MTBD] [beti]-encapsulated nanoporous NiPt alloy nanoparticles. Adv. Func. Mater. 23(44), 5494-5501 (2013). https://doi.org/10.1002/adfm.201301144

71. Zhang, G.R., Munoz, M., Etzold, B.J.: Accelerating oxygenreduction catalysts through preventing poisoning with non-reactive species by using hydrophobic ionic liquids. Angew. Chem. Int. Ed. 55(6), 2257-2261 (2016). https://doi.org/10.1002/anie. 201508338

72. Wang, M., Zhang, H., Thirunavukkarasu, G., Salam, I., Varcoe, J.R., Mardle, P., Li, X., Mu, S., Du, S.: Ionic liquid-modified microporous $\mathrm{ZnCoNC}$-based electrocatalysts for polymer electrolyte fuel cells. ACS Energy Lett. 4(9), 2104-2110 (2019). https:// doi.org/10.1021/acsenergylett.9b01407

73. Li, Y., Intikhab, S., Malkani, A., Xu, B., Snyder, J.: Ionic liquid additives for the mitigation of nafion specific adsorption on 
platinum. ACS Catal. 10(14), 7691-7698 (2020). https://doi. org/10.1021/acscatal.0c01243

74. Mack, F., Klages, M., Scholta, J., Jörissen, L., Morawietz, T., Hiesgen, R., Kramer, D., Zeis, R.: Morphology studies on high-temperature polymer electrolyte membrane fuel cell electrodes. J. Power Sour. 255, 431-438 (2014). https://doi.org/10. 1016/j.jpowsour.2014.01.032

75. Dowd, R.P., Li, Y., Van, N.T.: Controlling the ionic polymer/ gas interface property of a PEM fuel cell catalyst layer during membrane electrode assembly fabrication. J. Appl. Electrochem. 50(10), 993-1006 (2020). https://doi.org/10.1007/ s10800-020-01453-w

76. Hou, Y., Deng, H., Pan, F., Chen, W., Du, Q., Jiao, K.: Porescale investigation of catalyst layer ingredient and structure effect in proton exchange membrane fuel cell. Appl. Energy 253, 113561 (2019). https://doi.org/10.1016/j.apenergy.2019. 113561

77. Wang, M., Park, J.H., Kabir, S., Neyerlin, K.C., Kariuki, N.N., Lv, H., Stamenkovic, V.R., Myers, D.J., Ulsh, M., Mauger, S.A.: Impact of catalyst ink dispersing methodology on fuel cell performance using in-situ X-ray scattering. ACS Appl. Energy Mater. 2(9), 6417-6427 (2019). https://doi.org/10.1021/acsaem. $9 \mathrm{~b} 01037$

78. Yamada, H., Kato, H., Kodama, K.: Cell performance and durability of Pt/C cathode catalyst covered by dopamine derived carbon thin layer for polymer electrolyte fuel cells. J. Electrochem. Soc. 167(8), 084508 (2020). https://doi.org/10.1149/1945-7111/ ab8b97

79. Zhou, F., Yan, Y., Guan, S., Guo, W., Sun, M., Pan, M.: Solving nafion poisoning of ORR catalysts with an accessible layer: designing a nanostructured core-shell $\mathrm{Pt} / \mathrm{C}$ catalyst via a one-step self-assembly for PEMFC. Int. J. Energy Res. 44(13), 1015510167 (2020). https://doi.org/10.1002/er.5629

80. Orfanidi, A., Madkikar, P., El-Sayed, H.A., Harzer, G.S., Kratky, T., Gasteiger, H.A.: The key to high performance low Pt loaded electrodes. J. Electrochem. Soc. 164(4), F418-F426 (2017). https://doi.org/10.1149/2.1621704jes

81. Chen, M., Zhao, C., Sun, F., Fan, J., Li, H., Wang, H.: Research progress of catalyst layer and interlayer interface structures in membrane electrode assembly (MEA) for proton exchange membrane fuel cell (PEMFC) system. eTransportation 5, 100075 (2020). https://doi.org/10.1016/j.etran.2020.100075

82. Kim, Y.S., Welch, C.F., Mack, N.H., Hjelm, R.P., Orler, E.B., Hawley, M.E., Lee, K.S., Yim, S.D., Johnston, C.M.: Highly durable fuel cell electrodes based on ionomers dispersed in glycerol. Phys. Chem. Chem. Phys. 16(13), 5927-5932 (2014). https://doi.org/10.1039/c4cp00496e

83. Jung, C.Y., Yi, S.C.: Improved polarization of mesoporous electrodes of a proton exchange membrane fuel cell using $\mathrm{N}$-methyl2-pyrrolidinone. Electrochim. Acta 113, 37-41 (2013). https:// doi.org/10.1016/j.electacta.2013.09.041

84. Choo, M.J., Oh, K.H., Kim, H.T., Park, J.K.: Modulated ionomer distribution in the catalyst layer of polymer electrolyte membrane fuel cells for high temperature operation. Chemsuschem 7(8), 2335-2341 (2014). https://doi.org/10.1002/cssc.201402015

85. Kim, T.H., Yi, J.Y., Jung, C.Y., Jeong, E., Yi, S.C.: Solvent effect on the Nafion agglomerate morphology in the catalyst layer of the proton exchange membrane fuel cells. Int. J. Hydrogen Energy 42(1), 478-485 (2017). https://doi.org/10.1016/j.ijhyd ene.2016.12.015

86. Karan, K.: PEFC catalyst layer: recent advances in materials, microstructural characterization, and modeling. Curr. Opin. Electrochem. 5(1), 27-35 (2017). https://doi.org/10.1016/j.coelec. 2017.08.018

87. Van, C.T., Khandavalli, S., Chowdhury, A., Medina, S., Pylypenko, S., Wang, M., More, K.L., Kariuki, N., Myers, D.J.,
Weber, A.Z., Mauger, S.A., Ulsh, M., Neyerlin, K.C.: Dictating Pt-based electrocatalyst performance in polymer electrolyte fuel cells, from formulation to application. ACS Appl. Mater. Interfaces. 11(50), 46953-46964 (2019). https://doi.org/10.1021/ acsami.9b17614

88. Lee, J., Liu, H., George, M.G., Banerjee, R., Ge, N., Chevalier, S., Kotaka, T., Tabuchi, Y., Bazylak, A.: Microporous layer to carbon fibre substrate interface impact on polymer electrolyte membrane fuel cell performance. J. Power Sour. 422, 113-121 (2019). https://doi.org/10.1016/j.jpowsour.2019.02.099

89. Wu, H.W.: A review of recent development: transport and performance modeling of PEM fuel cells. Appl. Energy 165, 81-106 (2016). https://doi.org/10.1016/j.apenergy.2015.12.075

90. Song, Y., Wei, Y., Xu, H., Williams, M., Liu, Y., Bonville, L.J., Russell, K., Fenton, H.: Improvement in high temperature proton exchange membrane fuel cells cathode performance with ammonium carbonate. J. Power Sour. 141(2), 250-257 (2005). https:// doi.org/10.1016/j.jpowsour.2004.09.021

91. Kim, W.K., Sung, K.A., Oh, K.H., Choo, M.J., Cho, K.Y., Cho, K.Y., Park, J.K.: A new catalyst layer based on in situ pore generation of sulfonated poly(ether ether ketone) for PEMFC. Electrochem. Commun. 11(8), 1714-1716 (2009). https://doi.org/10. 1016/j.elecom.2009.07.003

92. Harzer, G.S., Orfanidi, A., El-Sayed, H., Madkikar, P., Gasteiger, H.A.: Tailoring catalyst morphology towards high performance for low Pt loaded PEMFC cathodes. J. Electrochem. Soc. 165(10), F770-F779 (2018). https://doi.org/10.1149/2.03118 10 jes

93. Suzuki, T., Tsushima, S., Hirai, S.: Effects of Nafion ${ }^{\circledR}$ ionomer and carbon particles on structure formation in a proton-exchange membrane fuel cell catalyst layer fabricated by the decal-transfer method. Int. J. Hydrogen Energy 36(19), 12361-12369 (2011). https://doi.org/10.1016/j.ijhydene.2011.06.090

94. Salari, S., Stumper, J., Bahrami, M.: Direct measurement and modeling relative gas diffusivity of PEMFC catalyst layers: The effect of ionomer to carbon ratio, operating temperature, porosity, and pore size distribution. Int. J. Hydrogen Energy 43(34), 16704-16718 (2018). https://doi.org/10.1016/j.ijhydene.2018.07. 035

95. Taghiabadi, M.M., Zhiani, M., Shafiei, M.: Influence of the cathode catalyst layer void volume on the short-term and long-term performance of PEM fuel cell. Fuel Cells 18(6), 731-741 (2018). https://doi.org/10.1002/fuce.201800023

96. Sassin, M.B., Garsany, Y., Atkinson, R.W., Hjelm, R.M., SwiderLyons, K.E.: Understanding the interplay between cathode catalyst layer porosity and thickness on transport limitations en route to high-performance PEMFCs. Int. J. Hydrogen Energy 44(31), 16944-16955 (2019). https://doi.org/10.1016/j.ijhydene.2019.04. 194

97. Pournemat, A., Markötter, H., Wilhelm, F., Enz, S., Kropf, H., Manke, I., Scholta, J.: Nano-scale monte carlo study on liquid water distribution within the polymer electrolyte membrane fuel cell microporous layer, catalyst layer and their interfacial region. J. Power Sour. 397, 271-279 (2018). https://doi.org/10.1016/j. jpowsour.2018.07.027

98. Roh, C.W., Choi, J., Lee, H.: Hydrophilic-hydrophobic dual catalyst layers for proton exchange membrane fuel cells under low humidity. Electrochem. Commun. 97, 105-109 (2018). https:// doi.org/10.1016/j.elecom.2018.11.003

99. Oh, K.H., Kim, W.K., Sung, K.A., Choo, M.J., Nam, K.W., Choi, J.W., Park, J.K.: A hydrophobic blend binder for anti-water flooding of cathode catalyst layers in polymer electrolyte membrane fuel cells. Int. J. Hydrogen Energy 36(21), 13695-13702 (2011) https://doi.org/10.1016/j.ijhydene.2011.07.116

100. Li, A., Chan, S.H., Nguyen, N.T.: Anti-flooding cathode catalyst layer for high performance PEM fuel cell. Electrochem. 
Commun. 11(4), 897-900 (2009). https://doi.org/10.1016/j.elecom.2009.02.022

101. Chi, B., Ye, Y., Lu, X., Jiang, S., Du, L., Zeng, J., Ren, J., Liao, S.: Enhancing membrane electrode assembly performance by improving the porous structure and hydrophobicity of the cathode catalyst layer. J. Power Sour. 443, 227-284 (2019). https:// doi.org/10.1016/j.jpowsour.2019.227284

102. Reshetenko, T.V., St-Pierre, J.: Separation method for oxygen mass transport coefficient in gas and ionomer phases in PEMFC GDE. J. Electrochem. Soc. 161(10), F1089-F1100 (2014). https://doi.org/10.1149/2.1021410jes

103. Jung, C.Y., Kim, S.K., Lee, S.J., Yi, S.C.: Three-dimensional reconstruction of coarse-dense dual catalyst layer for proton exchange membrane fuel cells. Electrochim. Acta 211, 142-147 (2016). https://doi.org/10.1016/j.electacta.2016.06.040

104. Suzuki, T., Nakata, Y., Tsutsui, F., Tsushima, S.: Investigation of gas transport properties of PEMFC catalyst layers using a microfluidic device. J. Electrochem. Soc. 167(12), 124519 (2020). https://doi.org/10.1149/1945-7111/abaf28

105. Shen, J., Zhou, J., Astrath, N.G., Navessin, T., Liu, Z.S., Lei, C., Rohling, J.H., Bessarabov, D., Knights, S., Ye, S.: Measurement of effective gas diffusion coefficients of catalyst layers of PEM fuel cells with a Loschmidt diffusion cell. J. Power Sour. 196(2), 674-678 (2011). https://doi.org/10.1016/j.jpowsour.2010.07.086

106. Middelman, E.: Improved PEM fuel cell electrodes by controlled self-assembly. Fuel Cells Bull. 2002(11), 9-12 (2002). https:// doi.org/10.1016/S1464-2859(02)11028-5

107. Lu, Y., Du, S., Steinberger-Wilckens, R.: One-dimensional nanostructured electrocatalysts for polymer electrolyte membrane fuel cells—a review. Appl. Catal. B 199, 292-314 (2016). https://doi. org/10.1016/j.apcatb.2016.06.022

108. Wang, G., Zou, L., Huang, Q., Zou, Z., Yang, H.: Multidimensional nanostructured membrane electrode assemblies for proton exchange membrane fuel cell applications. J. Mater. Chem. A 7(16), 9447-9477 (2019). https://doi.org/10.1039/C8TA12382A

109. Tian, Z.Q., Lim, S.H., Poh, C.K., Tang, Z., Xia, Z., Luo, Z., Shen, P.K., Chua, D., Feng, Y.P., Shen, Z., Lin, J.: A highly order-structured membrane electrode assembly with vertically aligned carbon nanotubes for ultra-low Pt loading PEM fuel cells. Adv. Energy Mater. 1(6), 1205-1214 (2011). https://doi.org/10. 1002/aenm.201100371

110. Debe, M.K., Hendricks, S.M., Vernstrom, G.D., Meyers, M., Brostrom, M., Stephens, M., Chan, Q., Willey, J., Hamden, M., Mittelsteadt, C.K., Capuano, C.B., Ayers, K.E., Anderson, E.B.: Initial performance and durability of ultra-low loaded NSTF electrodes for PEM electrolyzers. J. Electrochem. Soc. 159(6), K165-K176 (2012). https://doi.org/10.1149/2.065206jes

111. Chan, K., Eikerling, M.: Water balance model for polymer electrolyte fuel cells with ultrathin catalyst layers. Phys. Chem. Chem. Phys. 16(5), 2106-2117 (2014). https://doi.org/10.1039/ C3CP54849J

112. Jiang, S., Yi, B., Cao, L., Song, W., Zhao, Q., Yu, H., Shao, $\mathrm{Z}$.: Development of advanced catalytic layer based on vertically aligned conductive polymer arrays for thin-film fuel cell electrodes. J. Power Sources 329, 347-354 (2016). https://doi.org/ 10.1016/j.jpowsour.2016.08.098

113. Xia, Z., Wang, S., Jiang, L., Sun, H., Liu, S., Fu, X., Zhang, B., Sheng, S.D., Wang, J., Sun, G.: Bio-inspired construction of advanced fuel cell cathode with Pt anchored in ordered hybrid polymer matrix. Sci. Rep. 5(1), 16100 (2015). https://doi.org/10. 1038/srep16100

114. Sun, R., Xia, Z., Shang, L., Fu, X., Li, H., Wang, S., Sun, G.: Hierarchically ordered arrays with platinum coated PANI nanowires for highly efficient fuel cell electrodes. J. Mater. Chem. A 5(29), 15260-15265 (2017). https://doi.org/10.1039/C7TA0 $2500 \mathrm{~A}$
115. Mardle, P., Ji, X., Wu, J., Guan, S., Dong, H., Du, S.: Thin film electrodes from Pt nanorods supported on aligned N-CNTs for proton exchange membrane fuel cells. Appl. Catal. B 260, 118031 (2020). https://doi.org/10.1016/j.apcatb.2019.118031

116. Rajalakshmi, N., Lakshmi, N., Dhathathreyan, K.S.: Nano titanium oxide catalyst support for proton exchange membrane fuel cells. Int. J. Hydrogen Energy 33(24), 7521-7526 (2008). https:// doi.org/10.1016/j.ijhydene.2008.09.032

117. Heinzl, C., Hengge, K.A., Perchthaler, M., Hacker, V., Scheu, C.: Insight into the degradation of HT-PEMFCs containing tungsten oxide catalyst support material for the anode. J. Electrochem. Soc. 162(3), F280-F290 (2014). https://doi.org/10.1149/2.05415 03jes

118. Zhang, C., Yu, H., Li, Y., Fu, L., Gao, Y., Song, W., Shao, Z., Yi, B.: Highly stable ternary tin-palladium-platinum catalysts supported on hydrogenated $\mathrm{TiO} 2$ nanotube arrays for fuel cells. Nanoscale 5(15), 6834-6841 (2013). https://doi.org/10.1039/ c3nr01086d

119. Chen, M., Wang, M., Yang, Z., Wang, X.: High performance and durability of order-structured cathode catalyst layer based on $\mathrm{TiO}$ 2 @ PANI core-shell nanowire arrays. Appl. Surf. Sci. 406, 69-76 (2017). https://doi.org/10.1016/j.apsusc.2017.01.296

120. Jiang, S., Yi, B., Zhang, C., Liu, S., Yu, H., Shao, Z.: Vertically aligned carbon-coated titanium dioxide nanorod arrays on carbon paper with low platinum for proton exchange membrane fuel cells. J. Power Sour. 276, 80-88 (2015). https://doi.org/10.1016/j. jpowsour.2014.11.093

121. $\mathrm{Du}, \mathrm{S}$.: A facile route for polymer electrolyte membrane fuel cell electrodes with in situ grown Pt nanowires. J. Power Sour. 195(1), 289-292 (2010). https://doi.org/10.1016/j.jpowsour. 2009.06.091

122. Du, S.: Pt-based nanowires as electrocatalysts in proton exchange fuel cells. Int. J. Low-Carbon Technol. 7(1), 44-54 (2012). https://doi.org/10.1093/ijlct/ctr027

123. Lu, Y., Du, S., Steinberger-Wilckens, R.: Three-dimensional catalyst electrodes based on PtPd nanodendrites for oxygen reduction reaction in PEFC applications. Appl. Catal. B 187, 108-114 (2016). https://doi.org/10.1016/j.apcatb.2016.01.019

124. Lu, Y., Du, S., Steinberger-Wilckens, R.: Temperature-controlled growth of single-crystal Pt nanowire arrays for high performance catalyst electrodes in polymer electrolyte fuel cells. Appl. Catal. B 164, 389-395 (2015). https://doi.org/10.1016/j.apcatb.2014. 09.040

125. Du, S., Lin, K., Malladi, S.K., Lu, Y., Sun, S., Xu, Q., Steinberger-Wilckens, R., Dong, H.: Plasma nitriding induced growth of Pt-nanowire arrays as high performance electrocatalysts for fuel cells. Sci. Rep. 4, 6439 (2014). https://doi.org/10.1038/srep0 6439

126. Yao, X., Su, K., Sui, S., Mao, L., He, A., Zhang, J., Du, S.: A novel catalyst layer with carbon matrix for Pt nanowire growth in proton exchange membrane fuel cells (PEMFCs). Int. J. Hydrogen Energy 38(28), 12374-12378 (2013). https://doi.org/10. 1016/j.ijhydene.2013.07.037

127. Su, K., Yao, X., Sui, S., Wei, Z., Zhang, J., Du, S.: Matrix material study for in situ grown Pt nanowire electrocatalyst layer in proton exchange membrane fuel cells (PEMFCs). Fuel Cells 15(3), 449-455 (2015). https://doi.org/10.1002/fuce.201400168

128. Wei, Z., Su, K., Sui, S., He, A., Du, S.: High performance polymer electrolyte membrane fuel cells (PEMFCs) with gradient Pt nanowire cathodes prepared by decal transfer method. Int. J. Hydrogen Energy 40(7), 3068-3074 (2015). https://doi.org/10. 1016/j.ijhydene.2015.01.009

129. Sui, S., Wei, Z., Su, K., He, A., Wang, X., Su, Y., Hou, X., Raffet, S., Du, S.: Pt nanowire growth induced by Pt nanoparticles in application of the cathodes for polymer electrolyte membrane fuel cells (PEMFCs). Int. J. Hydrogen Energy 43(43), 
20041-20049 (2018). https://doi.org/10.1016/j.ijhydene.2018. 09.009

130. Fidiani, E., Thirunavukkarasu, G., Li, Y., Chiu, Y.L., Du, S.: Ultrathin AgPt alloy nanorods as low-cost oxygen reduction reaction electrocatalysts in proton exchange membrane fuel cells. J. Mater. Chem. A 8(23), 11874-11883 (2020). https://doi.org/10. 1039/D0TA02748K

131. Mardle, P., Thirunavukkarasu, G., Guan, S., Chiu, Y.L., Du, S.: Comparative study of PtNi nanowire array electrodes toward oxygen reduction reaction by half-cell measurement and PEMFC test. ACS Appl. Mater. Interfaces. 12(38), 42832-42841 (2020). https://doi.org/10.1021/acsami.0c11531

132. Marconot, O., Pauc, N., Buttard, D., Morin, A.: Vertically aligned platinum copper nanotubes as PEM fuel cell cathode: elaboration and fuel cell test. Fuel Cells 18(6), 723-730 (2018). https://doi. org/10.1002/fuce.201700242

133. Zeng, Y., Shao, Z., Zhang, H., Wang, Z., Hong, S., Yu, H., Yi, B.: Nanostructured ultrathin catalyst layer based on open-walled PtCo bimetallic nanotube arrays for proton exchange membrane fuel cells. Nano Energy 34, 344-355 (2017). https://doi.org/10. 1016/j.nanoen.2017.02.038

134. Shimpalee, S., Satjaritanun, P., Hirano, S., Tippayawong, N., Weidner, J.W.: Multiscale modeling of PEMFC using co-simulation approach. J. Electrochem. Soc. 166(8), F534-F543 (2019). https://doi.org/10.1149/2.0291911jes

135. Conde, J.J., Folgado, M.A., Ferreira-Aparicio, P., Chaparro, A.M., Chowdhury, A., Kusoglu, A., Cullen, D., Weber, A.Z.: Mass-transport properties of electrosprayed $\mathrm{Pt} / \mathrm{C}$ catalyst layers for polymer-electrolyte fuel cells. J. Power Sour. 427, 250-259 (2019). https://doi.org/10.1016/j.jpowsour.2019.04.079

136. Zhang, D., Cai, Q., Gu, S.: Three-dimensional lattice-Boltzmann model for liquid water transport and oxygen diffusion in cathode of polymer electrolyte membrane fuel cell with electrochemical reaction. Electrochim. Acta 262, 282-296 (2018). https://doi.org/ 10.1016/j.electacta.2017.12.189

137. Ramaswamy, N., Kumaraguru, S.: Materials and design selection to improve high current density performance in PEMFC. ECS Trans. 85(13), 835-842 (2018). https://doi.org/10.1149/08513. 0835ecst

138. Zhu, F., Luo, L., Wu, A., Wang, C., Cheng, X., Shen, S., Ke, C., Yang, H., Zhang, J.: Improving the high-current-density performance of PEMFC through much enhanced utilization of platinum electrocatalysts on carbon. ACS Appl. Mater. Interfaces. 12(23), 26076-26083 (2020). https://doi.org/10.1021/acsami.0c06981

139. Lee, H.Y., Kim, S.K., Lee, M.R., Peck, D.H., Kang, Y.C., Kim, C.S.: Reduced mass transport resistance in polymer electrolyte membrane fuel cell by polyethylene glycol addition to catalyst ink. Int. J. Hydrogen Energy 44(1), 354-361 (2019). https://doi. org/10.1016/j.ijhydene.2018.08.134

140. Wang, Y., Seo, B., Wang, B., Zamel, N., Jiao, K., Adroher, X.C.: Fundamentals, materials, and machine learning of polymer electrolyte membrane fuel cell technology. Energy and AI 1, 100014 (2020). https://doi.org/10.1016/j.egyai.2020.100014

141. Whiston, M.M., Azevedo, I.L., Litster, S., Whitefoot, K.S., Samaras, C., Whitacre, J.F.: Expert assessments of the cost and expected future performance of proton exchange membrane fuel cells for vehicles. Proc. Natl. Acad. Sci. 116(11), 4899-4904 (2019). https://doi.org/10.1073/pnas.1804221116

142. Yumiya, H., Kizaki, M., Asai, H.: Toyota fuel cell system (TFCS). World Electric Vehicle Journal 7(1), 85-92 (2015). https://doi.org/10.3390/wevj7010085

143. Lohse-Busch, H., Stutenberg, K., Duoba, M., Iliev, S.: Technology assessment of a fuel cell vehicle:2017 Toyota Mirai Argonne National Lab (ANL), Argonne (2018)

144. Volume Manufacturing of PEM FC Stacks for Transportation and In-line Quality Assurance. (2019). https://cordis.europa.eu/proje ct/id/671465.

145. DOE Technical Targets for Fuel Cell Systems and Stacks for Transportation Applications. (2020). https://www.energy.gov/ eere/fuelcells/doe-technical-targets-fuel-cell-systems-and-stackstransportation-applications.

146. STATE-OF-THE-ART AND FUTURE TARGETS(KPIS). (2020). https://www.fch.europa.eu/soa-and-targets.

147. Kurtz, J.M., Sprik, S., Saur, G., Onorato, S.: Fuel cell electric vehicle durability and fuel cell performance. National Renewable Energy Lab, United States (2019)

148. Strategy for Developing Hydrogen and Fuel-Cell Technologies Formulated. (2019). https://www.meti.go.jp/english/press/2019/ 0918_001.html.

149. Du, S.: Recent advances in electrode design based on one-dimensional nanostructure arrays for proton exchange membrane fuel cell applications. Engineering (2020). https://doi.org/10.1016/j. eng.2020.09.014 